\title{
THE SIGNIFICANCE OF HIATUS BEDS IN SHALLOW-WATER MUDSTONES: AN EXAMPLE FROM THE MIDDLE JURASSIC OF SWITZERLAND
}

\author{
ANDREAS WETZEL AND VINCENZO ALLIA \\ Geologisch-Paläontologisches Institut, Universität Basel, Bernoullistrasse 32, CH-4056 Basel, Switzerland \\ e-mail:wetzel@ubaclu.unibas.ch
}

\begin{abstract}
AвSTRACT: Limestone beds formed in nearly carbonate-free shallow-water mudstones by discontinuous sedimentation and erosion are called hiatus beds. Anaerobic oxidation of organic matter by microbes provided excess alkalinity, inducing carbonate precipitation. A multiphase history of such beds is documented from the Swiss Jurassic by several cementation and dissolution phases. Four cement types occur: micrite as earliest cement $\left(\delta^{13} \mathrm{C}-10\right.$ to $\left.-20 \%\right)$, stellate calcite between micrite-cemented parts $\left(\delta^{13} \mathrm{C}-5\right.$ to $\left.-10 \%\right)$, fibrous calcite cement in dissolution cavities $\left(\delta^{13} \mathrm{C}<-30 \%\right)$, and blocky calcite in remaining pores $\left(\delta^{13} \mathrm{C}-5 \%\right)$. Except for the late blocky cement, all cements contain pyrite, indicating carbonate precipitation within the sulfate reduction zone. After early cementation by micrite, the beds moved relatively upwards into a shallower geochemical zone and some even to the seafloor because of erosion. Cavities formed during reburial by dissolution in the upper part of the sulfate reduction zone and in the upper part of the methanogenic zone. Strongly reduced sedimentation rates provided the requisite stable geochemical conditions for at least several thousands of years, which permitted precipitation and dissolution of carbonate by biochemical processes and diffusion. This happened on short-lived swells caused by differential subsidence and rotation along listric faults when basement structures became reactivated during the extensional stress regime from opening of the Tethys. During the Jurassic and Cretaceous breakup of Pangea the shelf area increased, and differential subsidence on these newly formed shelves was the main factor responsible for the observed postPaleozoic maximum in hiatus beds and hiatus concretions.
\end{abstract}

\section{INTRODUCTION}

In predominantly fine-grained, siliciclastic sediments a break in sedimentation or seafloor erosion may be marked by a horizon of early diagenetic concretions, which have been referred to as "hiatus concretions" (Voigt 1968). In addition, certain limestone beds may form in this way (Raiswell 1988), which we suggest can be called "hiatus beds". Hiatus concretions show evidence that they hardened before exhumation, and cementation probably occurred not very deep below the sediment surface (e.g., Savrda and Bottjer 1988). It is considered a prerequisite for the growth of concretions that they reside for a considerable time ( $>7000$ years; Coleman and Raiswell 1993) within a specific geochemical environment, e.g., the sulfate reduction zone. Therefore, a significant interruption of sediment input may be sufficient to induce concretion formation (Spears 1989; Raiswell 1987), whereas seafloor erosion is not necessarily required. Disconformities in mudstones are inconspicuous if reworked concretions or hiatus beds are lacking (Fürsich and Baird 1975; Baird 1976). Hiatus beds, thus, have stratigraphic and sedimentologic value in that they allow identification of surfaces at which sedimentation was interrupted for a significant time. Such discontinuity surfaces are commonly not manifested as biostratigraphic gaps (e.g., Wilson 1985). If concretions are exhumed, they form hard bottoms and the epifauna changes in response to substrate consistency (e.g., Fürsich 1979).

Study of individual hiatus concretions and beds (e.g., Voigt 1968; Hallam 1969; Fürsich 1979) has revealed their complex, multiphase history; this includes (1) concretion formation; (2) concretion exhumation, (3) boring and/or encrustation; (4) burial; and (5) precipitation of additional cement. During phases 1 and 5 cracking and precipitation of additional cement may occur (e.g., Kennedy et al. 1977; Hesselbo and Palmer 1992). In terms of sequence stratigraphy, hiatus concretions and beds are genetically linked to rising or high sealevel (e.g., Van Wagoner et al. 1988). They occur at the initiation of transgressions (e.g., Voigt 1968; Fürsich et al. 1991). Furthermore, during the time of maximum rate of transgression they form in areas where the sediment input is strongly reduced ("condensed section" while clastics accumulate nearer to the land (e.g., Loutit et al. 1988). Similar deposits, thought to have formed during sealevel highstand, were also reported from drowned carbonate platforms by Kendall and Schlager (1981).

This simple sequence-stratigraphic interpretation of hiatus beds and condensed sections, however, is not always valid. Other processes, such as differential subsidence, can produce sediment starvation or seafloor erosion (e.g., Hesselbo and Palmer 1992) and thus provide the conditions necessary for formation of hiatus concretions.

It is the purpose of this study to demonstrate that hiatus beds in the Swiss Jurassic are useful for deciphering the effects of differential subsidence on the deposition of a thick mudstone sequence that accumulated rapidly in an epicontinental basin at a time of minor sealevel changes. The duration and type of discontinuous sediment input is reflected by the overall setting of the hiatus beds and the various cements therein. In general, hiatus beds seem to be formed more frequently during times of tectonic activity than of intense sealevel changes.

\section{STUDY AREA AND GEOLOGICAL BACKGROUND}

Several sections of Middle Jurassic mudstones were studied in northern Switzerland and southwestern Germany (Fig. 1). Because they accumulated mainly during
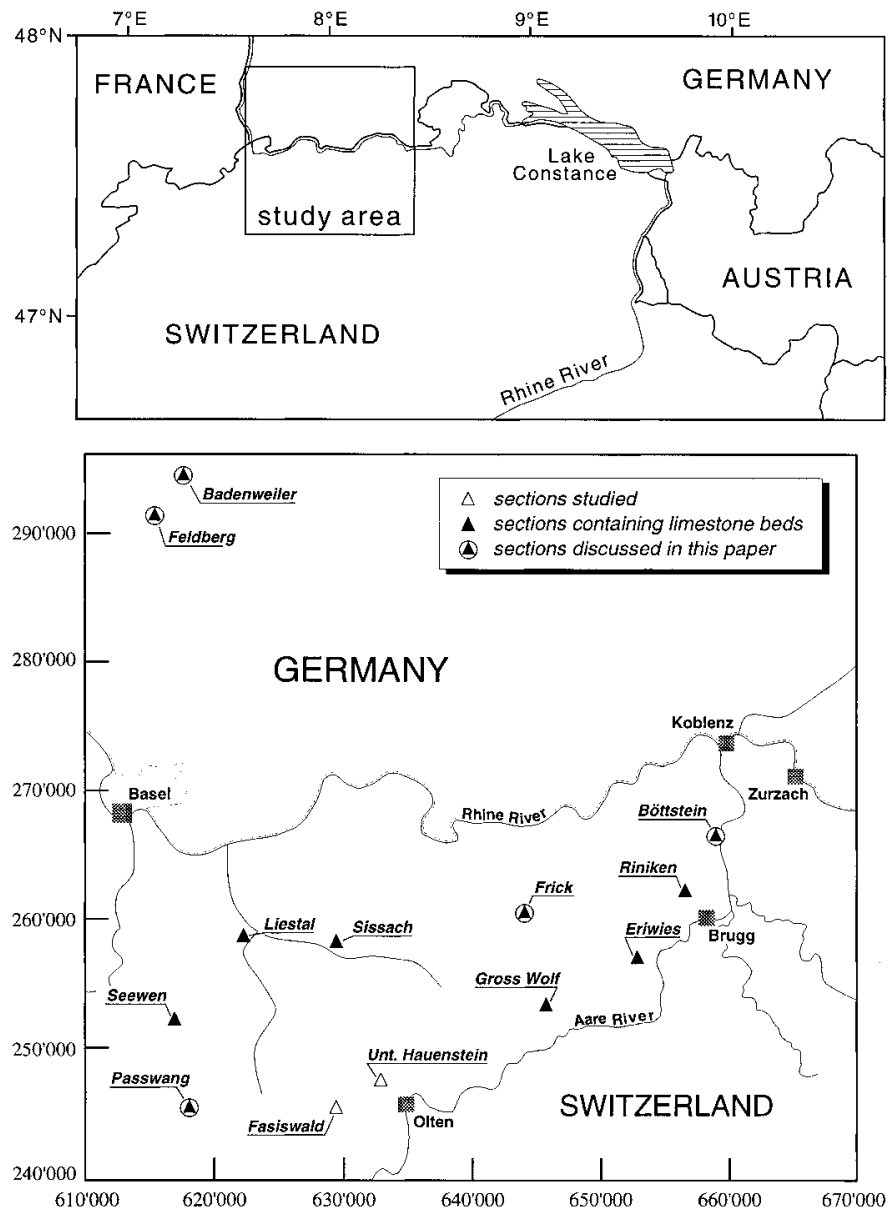

FIG. 1.-Location map of the study area in northern Switzerland and southwestern Germany (upper part), and the sections studied in detail (lower part). 


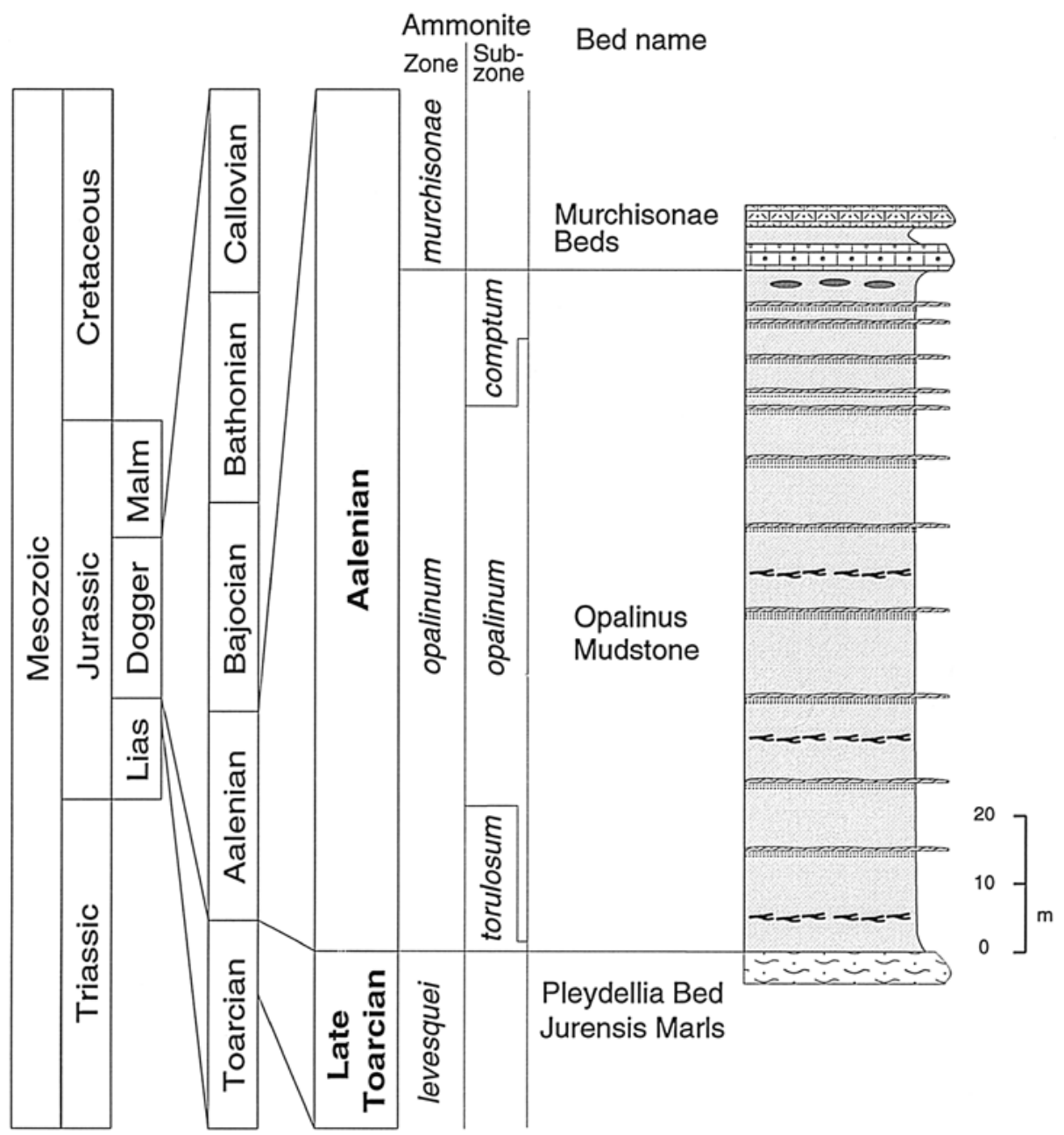

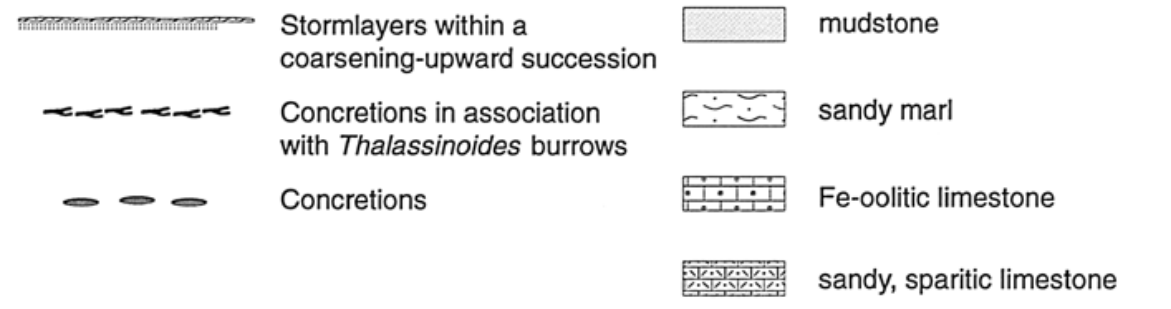

FIG. 2.-Schematic lithologic section for the Aalenian Opalinus Mudstone in northern Switzerland and southwestern Germany (after Allia 1996). In northern Switzerland the comptum and torulosum subzones are condensed whereas in southwestern Germany it is represented by several meters of sediments. The stratigraphic position of the storm layers, concretion-rich horizons, and bioturbated layers can vary from section to section. the Aalenian opalinum (but in southwest Germany also during the comptum and torulosum) ammonite subzone (Fig. 2), they are called "Opalinuston", translated as Opalinus Mudstone. The unit accumulated over a time interval of $1 \mathrm{Myr}$ when the time scale of Haq et al. (1987) is applied.

The Opalinus Mudstone accumulated in the southern part of an epicontinental sea that covered central Europe (Fig. 3; e.g., Ziegler 1990). Sediments were delivered from the Bohemian Massif in the northeast and the Rhenish Massif in the northwest, with a subordinate proportion from the Alemannic Land in the south. They consist of about $100 \mathrm{~m}$ of ostensibly monotonous dark gray mudstones. The organic-matter content in the present state is $0.5-1.5 \% \mathrm{C}_{\text {org }}$ dry weight. Macrofaunal remains are not uncommon, but often they are dissolved. The epifauna indicates aerobic to dysaerobic conditions at the bottom (Etter 1995; Schmidt 1996).

Within the mudstones millimeter- to decimeter-thick siliciclastic storm layers occur, often with oscillation ripples on top. Storm-wave-rippled sandstone beds occur in some intervals and suggest a depositional water depth close to or above the storm wave base, i.e., 20-30 m (Wetzel and Allia 1996; Allia 1996). Mudstone intervals might have been deposited in deeper water.

The accommodation space for the Opalinus Mudstone was provided by synsedimentary subsidence, because the sediment thickness of $100 \mathrm{~m}$ in the compacted state (corresponding to $250 \mathrm{~m}$ when deposited) clearly exceeded the depositional water depth of about $30 \mathrm{~m}$ and a sealevel rise of 10-20 m (Haq et al. 1987; Branger and Gonnin 1994). Subsidence was accelerated very likely by extension related to the opening of the Tethys and Atlantic Oceans (Wildi et al. 1989; Wetzel et al. 1993). The subsidence pattern was probably affected by a preexisting complex graben system (e.g., Laubscher 1986) and related faults in the basement that formed at the end of the Paleozoic.

\section{MATERIAL AND METHODS}

Thin sections of oriented samples were studied by light microscopy and by cold cathodoluminescence microscopy (CITL Mark II). Samples for oxygen and carbon isotope measurements were taken by a dental drill from the same pieces from which the thin sections were cut, so isotope samples can easily be related to the microscopically defined carbonate cement domains. The isotopes were measured by a VG Isogas PRISM mass spectrometer. Isotope compositions are expressed in notation as per mil deviations from the international PDB carbonate standard. Analytical precision based on routine analysis of the internal standard (Carrara Marble) was $\pm 0.10 \%$ for $\delta^{18} \mathrm{O}$ and $\pm 0.05 \%$ for $\delta^{13} \mathrm{C}$. 

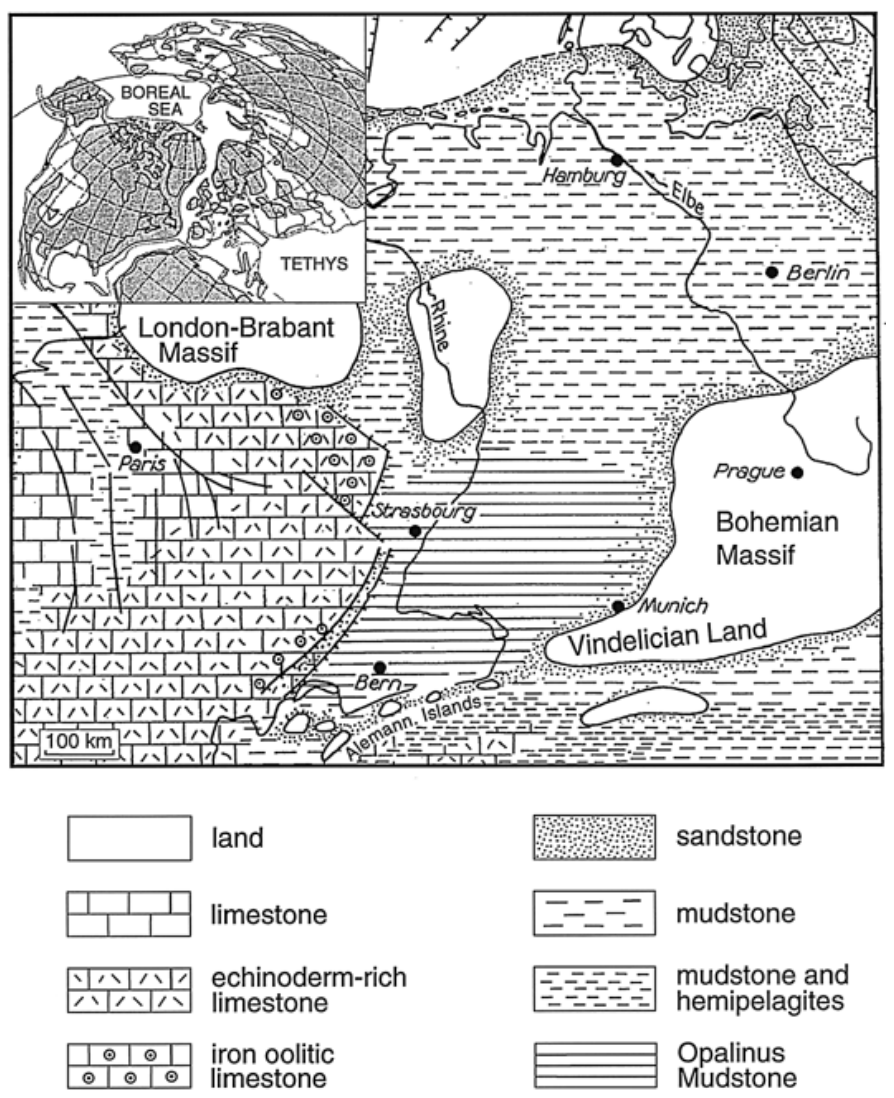

FIG. 3.-Paleogeography of central Europe during the Aalenian (after Ohmert and Rolf 1994, changed slightly); the study area was covered by an epicontinental sea where muddy sediments accumulated, but the area to the south and west was differentiated into swells and depressions. Insert shows the Northern Hemisphere; arrow points to present-day Switzerland.

\section{RESULTS}

Hiatus beds were found in 10 of 12 sections studied (Fig. 1); they occur at different positions within the stratigraphic sequence and in several horizons at some localities. The beds can be traced over several meters to tens of meters depending on the extent of an outcrop, but they can vary in thickness. Four categories of hiatus beds were recognized.

\section{Types of Hiatus Beds}

The various types were grouped between the two end members: bored and encrusted micrite nodules within a bioclastic host sediment (type I), and thick micritic beds having distinct internal structures (type IV).

Type I.-Ellipsoidal to round, gray micrite nodules, typically $5-8 \mathrm{~cm}$ in size, acted as a hard substrate on the seafloor and were bored and encrusted by organisms. They occur within wackestone containing primarily echinoderm and mollusc debris. The nodules and borings show a blackened rim enriched in pyrite (Fig. 4).

Type II.-Light gray, irregular-shaped to rounded micrite nodules, $1-5 \mathrm{~cm}$ across, occur in a bioclastic mudstone to wackestone and locally packstone. Bioclasts are echinoderm or mollusc debris. Some of the micrite nodules are homogeneous, whereas others display faint bioturbational structures. The nodules are only rarely bored or encrusted; most have a rim enriched in pyrite. Irregular, stromatactis-like voids occur in the vicinity of the nodules. These voids match nearly all criteria for stromatactis given by Bathurst (1982) except that they do not occur in muds of Paleozoic bioherms; therefore, they are called "stromatactis-like". The voids are filled with a brown-white color-banded calcite. Any remaining void space is occupied by blocky calcite or left open (Fig. 5)

Type III.-A gray to brownish bioclastic wackestone with micrite patches forms beds up to $10 \mathrm{~cm}$ thick. The micritic parts resemble nodules, but they have no sharp boundaries and lack borings and encrustation. In the matrix, stromatactis-like voids are up to $10 \mathrm{~cm}$ long and $2 \mathrm{~cm}$ high. Their long axes are roughly parallel to bedding. The margins of the voids are irregular. The void fill consists of a brown-white

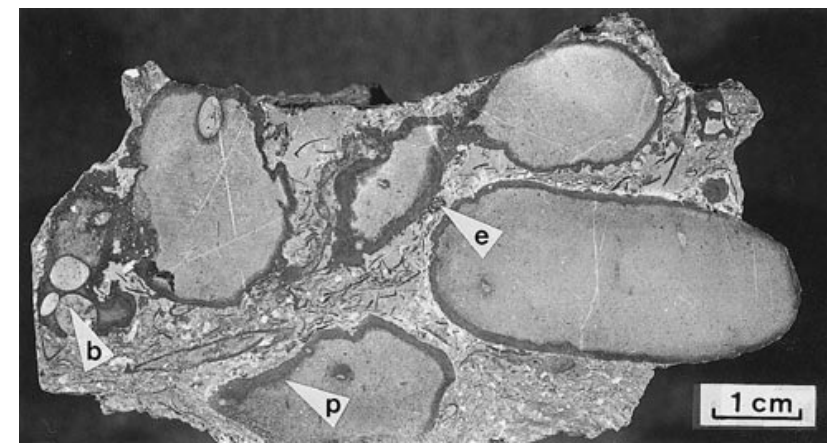

FIg. 4.-Vertical section of type I hiatus bed, consisting of micrite nodules with irregular corroded surfaces, borings (b), and encrusting organisms (e) embedded in a bioclastic wackestone. Margins of micrite nodules and borings are impregnated with pyrite $(\mathrm{p})$.

color-banded calcite, with remaining space occupied by white spar or still empty (Fig. 6).

Type IV.-Densely packed, coalescing dark gray micrite nodules form beds up to $20 \mathrm{~cm}$ thick. These nodules have an irregular, knobby surface when weathered. The most striking feature of these beds are irregular, connected cavities up to several decimeters long, which resemble miniaturized cave galleries (Fig. 7A). They have a remarkable fill: homogeneous, gray, rounded or irregular-shaped micritic nodules $1 \mathrm{~mm}$ to $1-2 \mathrm{~cm}$ in size that are surrounded by several generations of alternating brown to black and white calcite cement (Fig. 7). At least two phases of development can be deduced. First, a cavity system formed which is characterized by pyrite impregnation along its walls and around the nodules within it. During the second phase, nodule-filled cavities without a pyrite impregnation formed (Fig. 7B).

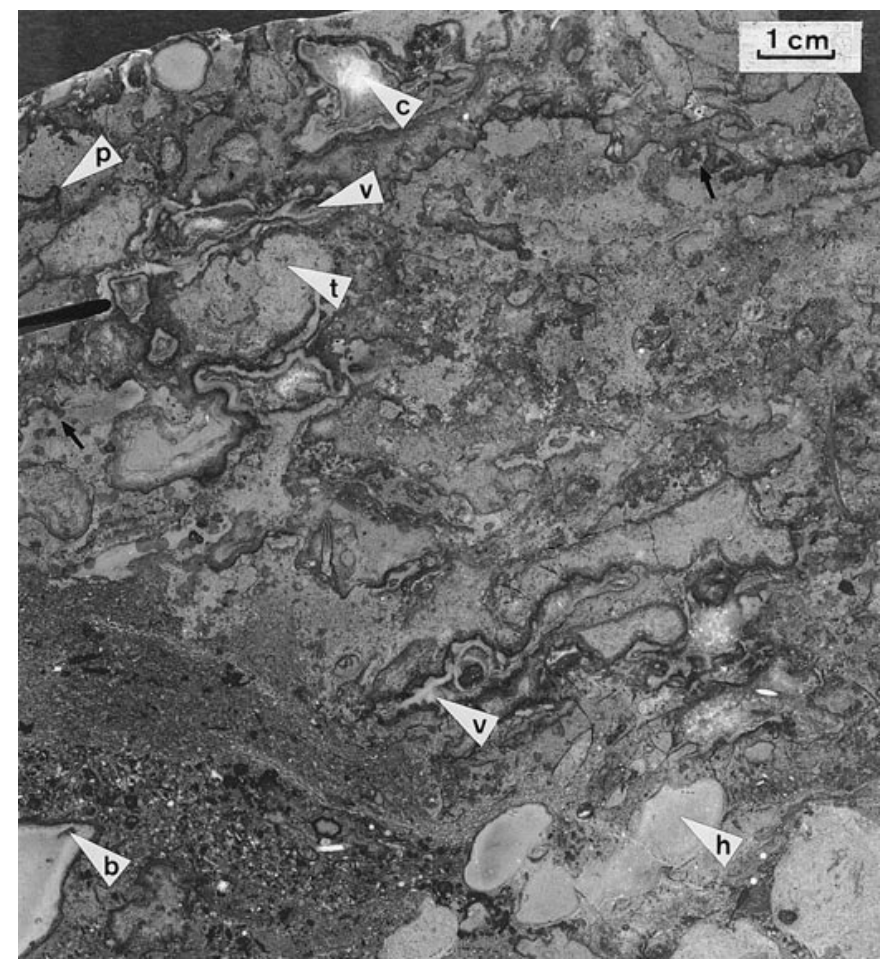

FIG. 5.- Vertical section of hiatus type II bed, consisting of irregular to round, homogeneous (h) or faintly bioturbated $(\mathrm{t})$ micritic nodules embedded in a lime mudstone to wackestone. Some nodules are indistinctly bored (b) but most are not. Some nodules are pyrite-rimmed (p). Some nodules have corroded margins (arrow). Voids (v) are filled by laminated cement and white calcite (c). 

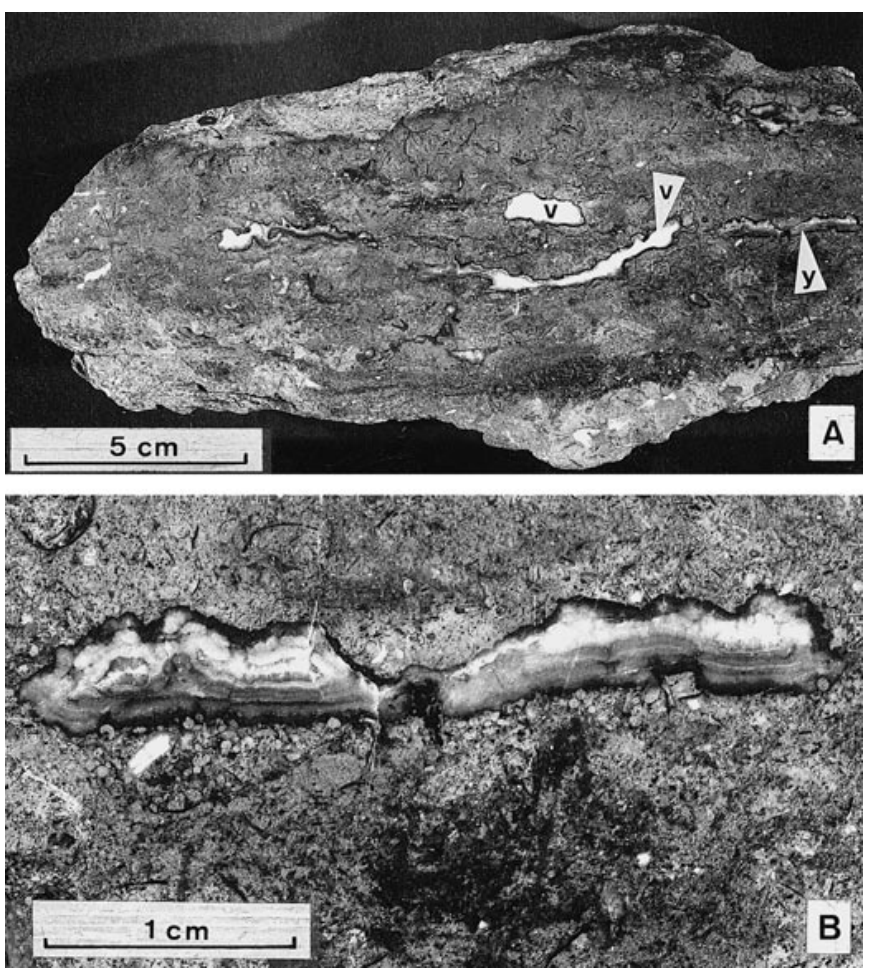

FIG. 6.-Vertical section of type III hiatus bed. A) Lime mudstone to wackestone with laminar stromatactis-like voids (v) having a brownish laminated cement along the margins followed by white calcite; void (y) is shown in part B. B) Laminated geopetal sediment within a stromatactis-like void.

\section{Cements}

The limestone beds contain several cement types, all of which are now calcite: micrite, stellate cement, fibrous cement, and blocky cement.

Micrite.-Micritic cement occurs mainly in nodules but also in other parts of the hiatus beds. The nodules contain fine-grained siliciclastic material, a varying amount of detrital quartz, bioclasts, and diagenetic euhedral pyrite (5-25 $\mu \mathrm{m}$ in size) (Fig. 8). The micrite is microscopically homogeneous; in only a few cases is a peloidal texture visible. The micrite shows a red, brownish-orange to brown cathode luminescence. The isotope values are $\delta^{13} \mathrm{C}-11$ to $-18 \%$ and $\delta^{18} \mathrm{O}-5$ to $-10 \%_{0}(12$ measurements). The isotope values do not vary significantly along a transect through a nodule for both $\delta^{13} \mathrm{C}$ and $\delta^{18} \mathrm{O}$. Micrite also occurs as cement between the nodules, which acted as pebbles after being exhumed.

Stellate Cement.-This cement type is similar in terms of size and morphology to the stellate crystals described by Roberts et al. (1993). Small elongate crystals, 20-80 $\mu \mathrm{m}$ long, are arranged nearly perpendicular to each other in three dimensions like the axes of an octahedron. Therefore, a mosaic with nearly perpendicular orientation of calcite crystals is observed in thin section (Fig. 9). Euhedral pyrite (10$20 \mu \mathrm{m}$ in diameter) occurs within the cement. Stellate cement occurs in the interstices between micrite nodules of beds of types I and II and fills borings (Figs. 8, 9). In the types II and III beds stellate cement co-occurs with micrite and surrounds quartz grains or bioclasts. In type IV beds stellate cement co-occurs with other cements within the cavity systems. The boundaries between stellate and other cements are sharp. Stellate cement luminesces red to brownish red, with small, dark brown to nonluminescent interstices, generally a little darker than the micrite. The $\delta^{13} \mathrm{C}$ isotope values range between -6 and $-13 \%$ and the $\delta^{18} \mathrm{O}$ values between -5 and $-9 \%$ ( 13 measurements).

Fibrous Cement.-Fibrous cement occurs in stromatactis-like voids and interconnected cavity systems of types II, III, and IV beds. It forms as laminae $0.2-1$ $\mathrm{mm}$ thick that alternate with seams $20-40 \mu \mathrm{m}$ thick rich in clay and pyrite (Fig. 10). Typically, the length of the crystals increases from $0.2 \mathrm{~mm}$ at the base of a void to $0.8-1.2 \mathrm{~mm}$ in the center (Fig. 10). The top of a fibrous cement generation is commonly corroded prior to being overlaid by blocky cement. The fibrous cement is cloudy and includes fluids and some small pyrite grains. The luminescence color is orange-red with some dark red to brownish banding related to layers enriched in clay and pyrite. Individual fibrous crystals are not visible under CL. The fibrous
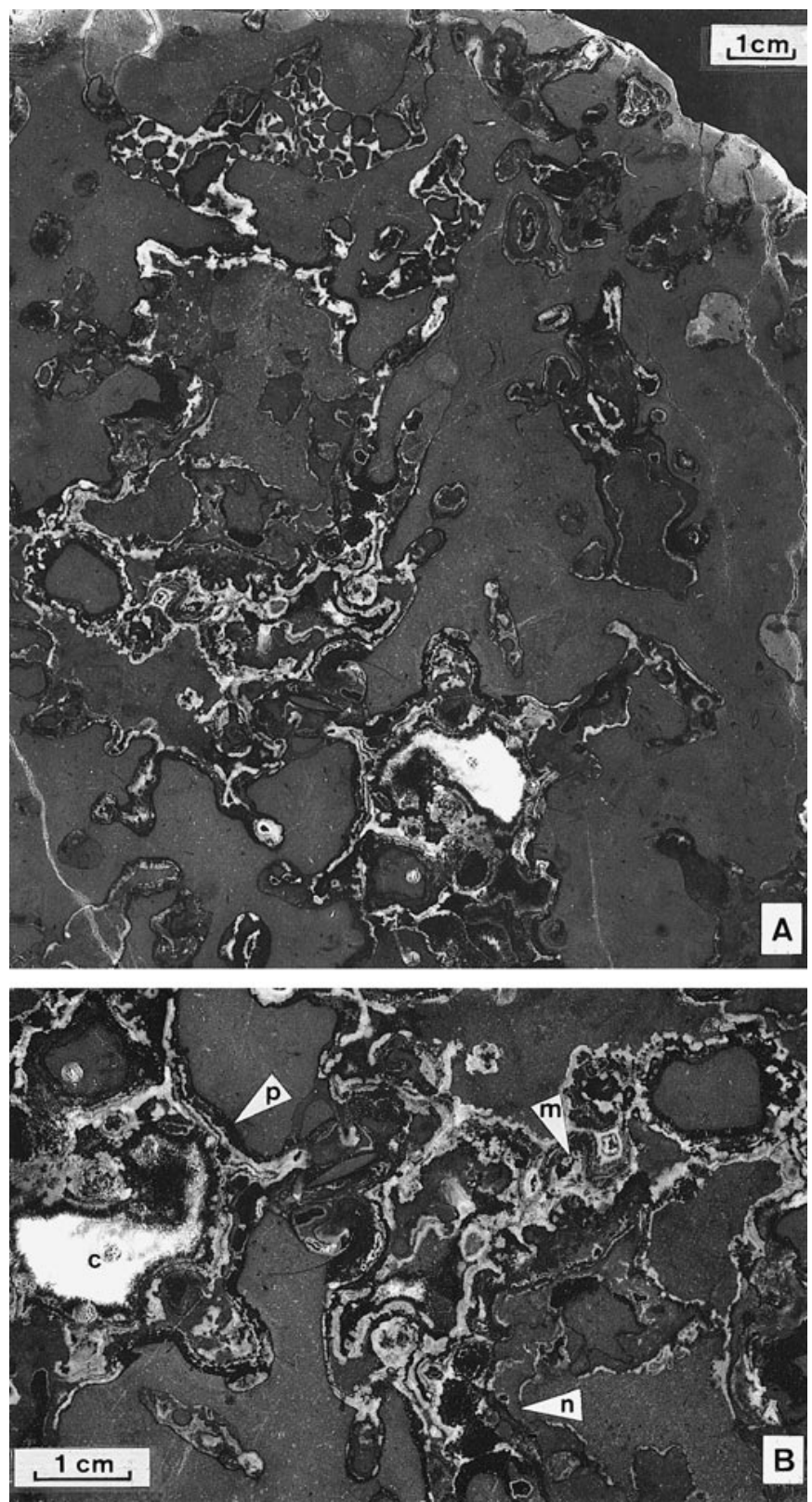

FIG. 7.-Horizontal section of type IV hiatus bed. A) Micritic bed having an extended cavity system filled with cement and nodules. B) Detailed view of the lower central part of part A showing the irregular cavity shape and the complex fill consisting of micrite nodules and multiple generations of cement (m). Some parts of walls and the nodules are impregnated with pyrite (p), whereas others are not (n). Remaining cavity space is filled with white calcite (c) or is still open.

cement has an isotopic signature of $\delta^{13} \mathrm{C}-34$ to $-39 \%$ and $\delta^{18} \mathrm{O}-2$ to $-5 \%$ o (9 measurements).

Blocky Cement.-Blocky cement fills the remaining pore space. Crystals range in size between 0.1 and $1 \mathrm{~mm}$, are clear, and do not contain pyrite. Although morphologically similar, two types of blocky cement can be distinguished with respect to their position within the void and cavity fills:

(1) Where blocky cement overlies corroded fibrous cement, the luminescence color is brown, dark brown, to dull; $\delta^{13} \mathrm{C}$ values vary between -3 to $-8 \%$ and $\delta^{18} \mathrm{O}$ between -5 to $-11 \%$ ( 7 measurements).

(2) Within the cavity systems some blocky cement is brownish where it surrounds micrite nodules. The luminescence color is orange. The isotope values are $\delta^{13} \mathrm{C}-5$ to $-7 \%$ and $\delta^{18} \mathrm{O}-6$ to $-9 \%$ ( 3 measurements). 


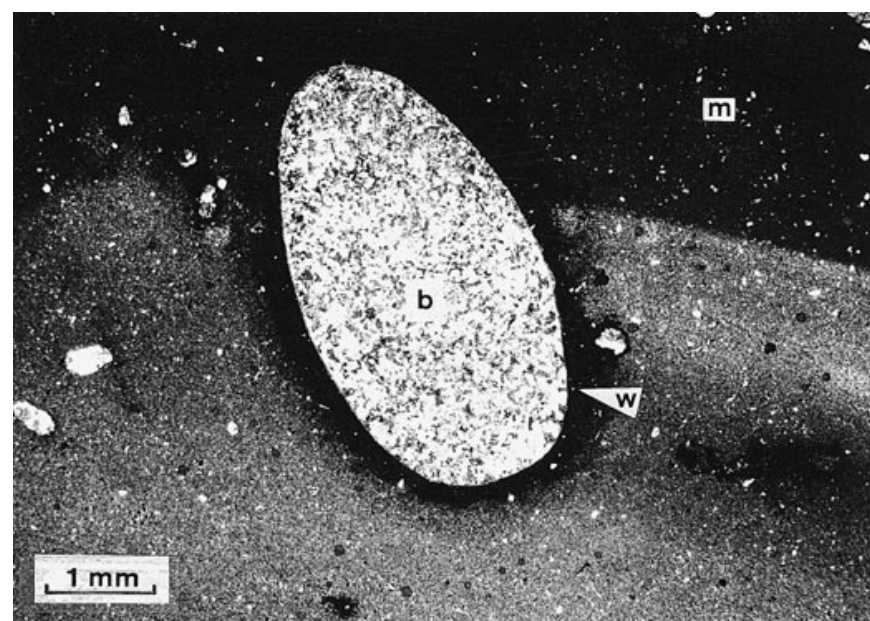

FIG. 8.-Thin section of exhumed, micrite cemented nodule (cross-polarized light). The boring (b) infilled with stellate cement (see Figure 9), the margin of the nodule (m), and the wall of boring (w) are enriched in pyrite (black staining).
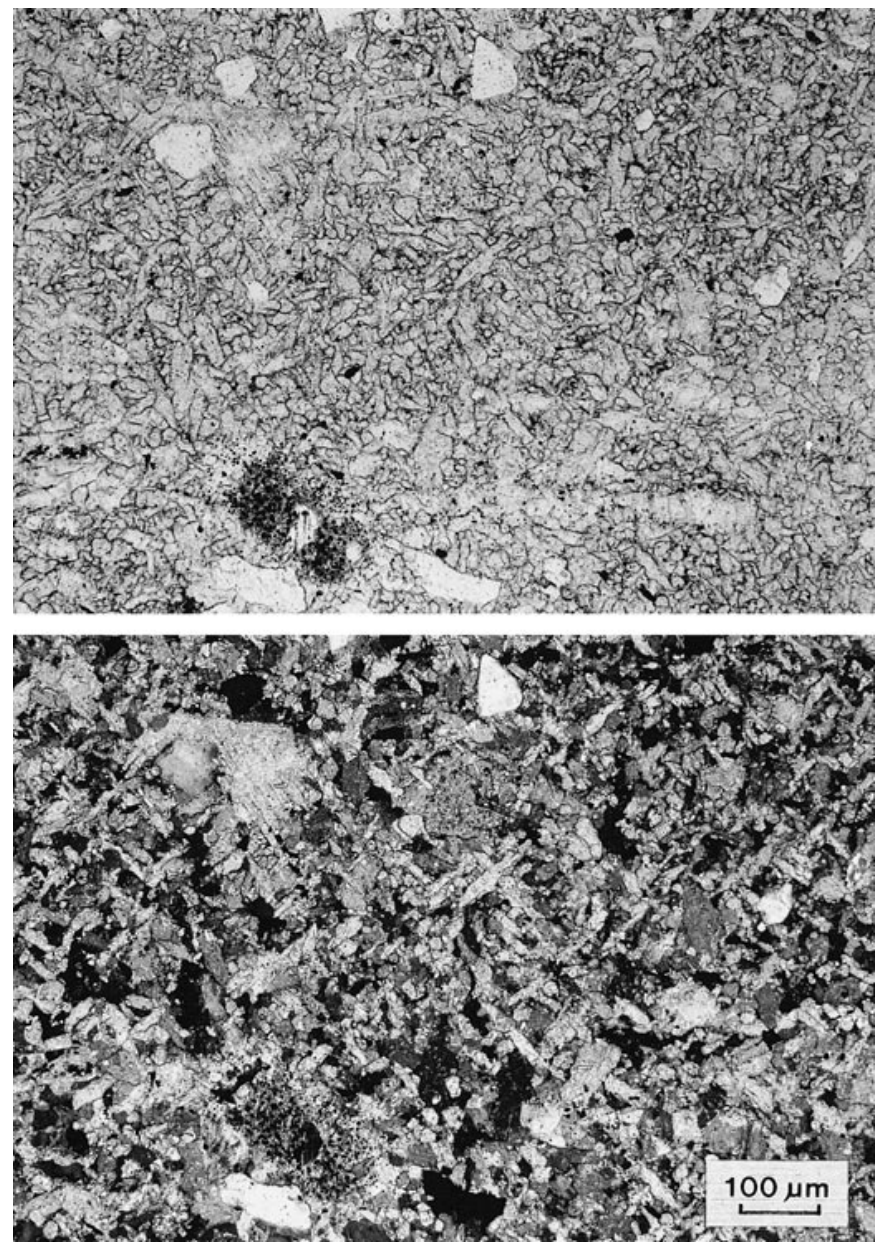

FIG. 9.-Stellate cement with scattered pyrite (small black grains) and quartz silt (white) in normal (upper part) and cross-polarized light (lower part).
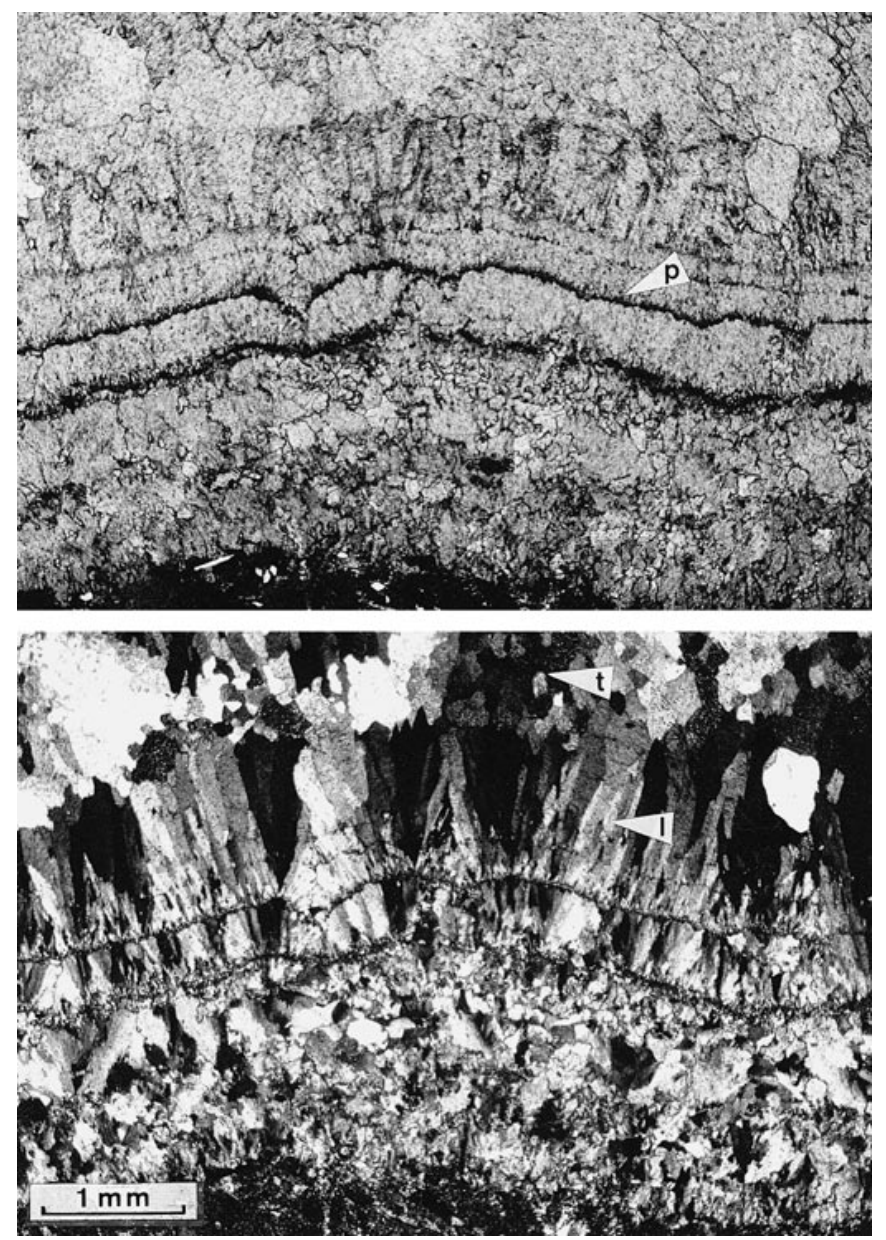

FIg. 10.-Fibrous cement found in stromatactis-like voids (see Figure 5B) in normal (upper part) and cross-polarized light. At the base, equant crystals are followed by successively more elongate fibrous cement interlayered with pyrite (p) seams. Transversally cut fibrous crystals $(t)$ are present on top of the longitudinally cut fibrous crystals (1).

\section{FORMATION OF HIATUS BEDS}

The macroscopic observations define the relative succession of processes and the minimum number of steps needed to form the limestone beds (Table 1); the microscopic observations, in addition, provide a cement stratigraphy. When both sets of observations are related to the geochemical data, they allow estimation of the relative depth below the seafloor at which the cements were precipitated.

\section{Geochemical Zones}

The succession of geochemical zones within sediments is known from the porewater composition of modern sediments and the minerals precipitated therefrom

TABLE 1.-Macroscopically identified steps in formation of hiatus beds

\begin{tabular}{|c|c|c|c|}
\hline Type I & Type II & Type III & Type IV \\
\hline $\begin{array}{l}\text { Formation of micrite } \\
\text { nodules }\end{array}$ & $\begin{array}{l}\text { Formation of micrite } \\
\text { nodules }\end{array}$ & $\begin{array}{l}\text { Micrite cementation } \\
\text { (diffuse nodules) }\end{array}$ & $\begin{array}{l}\text { Micrite cementation (co- } \\
\text { alescing nodules) }\end{array}$ \\
\hline Exhumation of nodules & Exhumation of nodules & $\begin{array}{l}\text { Slight erosion of sea- } \\
\text { floor }\end{array}$ & $\begin{array}{l}\text { Slight erosion of sea- } \\
\text { floor }\end{array}$ \\
\hline Boring and encrustation & Boring & & $\begin{array}{l}\text { Formation of cavity sys- } \\
\text { tem }\end{array}$ \\
\hline \multirow[t]{3}{*}{$\begin{array}{l}\text { Pyrite precipitation and } \\
\text { cementation }\end{array}$} & $\begin{array}{l}\text { Pyrite precipitation and } \\
\text { cementation }\end{array}$ & $\begin{array}{l}\text { Pyrite precipitation and } \\
\text { cementation }\end{array}$ & $\begin{array}{l}\text { Pyrite and carbonate } \\
\text { precipitation }\end{array}$ \\
\hline & Void formation & Void formation & $\begin{array}{l}\text { Further development of } \\
\text { cavity system }\end{array}$ \\
\hline & Filling of voids & Filling of voids & Filling of cavity system \\
\hline
\end{tabular}




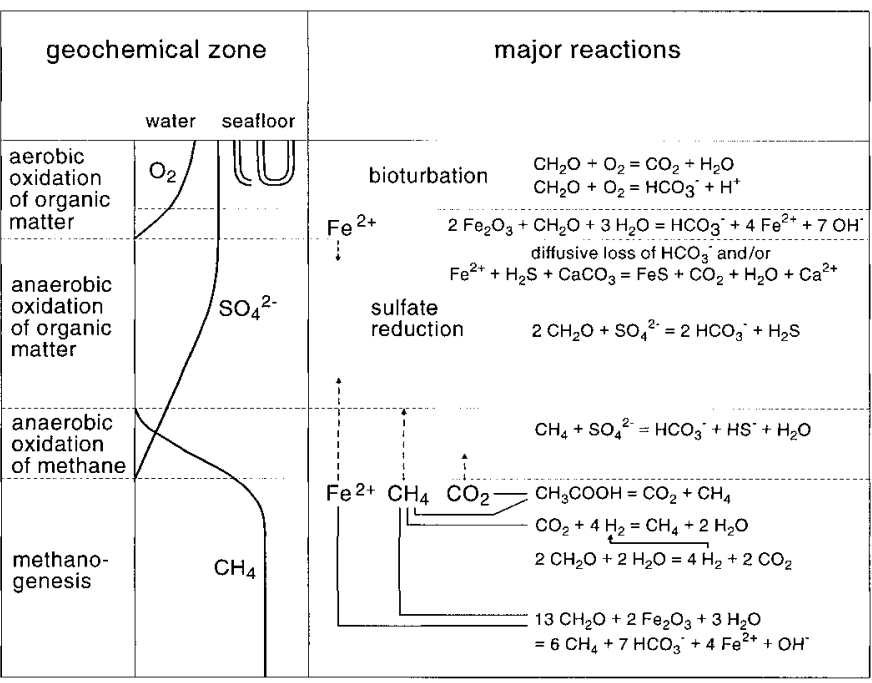

FIG. 11.-Geochemical zones in the studied sediments as reconstructed in analogy to modern environments and fossil counterparts (equations in lines 1, 6, 7, 8, and 9 after Whiticar (1996), in lines 2, 3, and 5 after Spears (1989), in line 4 after Canfield and Raiswell (1991), and in line 10 after Raiswell (1987); however, this reaction takes place only if sufficient iron is available).

(e.g., Claypool and Kaplan 1974; Curtis et al. 1986; Balzer et al. 1987; Coleman 1993; Middleton and Nelson 1996; Whiticar 1996; and references therein) and is summarized in Figure 11. The amount of buried organic matter and the sedimentation rate control the vertical extent of these zones.

In the uppermost zone, close to the seafloor, dissolved oxygen and sulfate occur. First, oxygen is consumed by aerobic oxidation of organic matter. Then $\mathrm{Mn}$ and $\mathrm{Fe}$ act as electron receptors, the latter possibly involved in precipitation of Fe sulfides. Farther down, sulfate is reduced by anaerobic oxidation of organic matter (Fig. 11). Within the upper part of the sulfate-reduction zone sulfide can provide an acidic environment as the alkalinity generated diffuses into the overlying seawater and/or precipitation of $\mathrm{Fe}$ sulfide provides additional $\mathrm{H}^{+}$(Fig. 11); the excess $\mathrm{H}^{+}$is buffered by dissolution of carbonate (e.g., Mettraux et al. 1989; Canfield and Raiswell 1991). Beyond the sulfate reducing zone, remaining organic matter can be converted to $\mathrm{CO}_{2}$ and methane (Fig. 11). Methane can diffuse upward and is anaerobically oxidized in the sulfate reduction zone, providing excess alkalinity for carbonate precipitation. Methanogenesis, however, generates $\mathrm{CO}_{2}$ rather than alkalinity, hence porewater in the methanogenic zone can approach undersaturation with respect to $\mathrm{CaCO}_{3}$ at a certain depth zone, especially if reactive $\mathrm{Fe}$ is low (Coleman and Raiswell 1993) and thus cause dissolution. In general, the bulk carbon phase will still retain the approximate isotopic signature of the organic matter from which $\mathrm{CO}_{2}$ and methane phases were initially derived, i.e. -25 to $-30 \%$. During further kinetic fractionation the residual methane becomes heavier and the bicarbonate produced becomes lighter than the $\mathrm{CH}_{4}$ from which it was derived (e.g., Raiswell 1987). Carbonate precipitated within one of these depth zones is characterized by its $\delta^{13} \mathrm{C}$ isotope signature (Fig. 11) reflecting aerobic oxidation of organic matter, anaerobic oxidation of organic matter within the zone of sulfate reduction, or anaerobic oxidation of methane (e.g., Anderson and Arthur 1983). Because of carbonate dissolution, any mixing with other carbonate sources can affect the isotope signature (e.g., Raiswell 1987).

The absolute depth values within the sediment can be roughly estimated by comparisons with modern analogues and by analyzing the spatial relation of nodule-rich horizons to the previous sediment surface. For this purpose shallow-marine settings with the same sedimentation rate were considered. The average sedimentation rate of the Opalinus Mudstone is estimated by total thickness versus time of deposition. After decompaction from a present-day porosity of $15 \%$ to $75 \%$ when deposited (Wetzel 1990), the sedimentation rate was in the order of $30 \mathrm{~cm} / \mathrm{kyr}$ at the seafloor. In modern argillaceous analogues with sedimentation rates of about $30 \mathrm{~cm} / \mathrm{kyr}$, the sulfate reduction zone extends from $20 \mathrm{~cm}$ to about $120 \mathrm{~cm}$ below the sediment surface (e.g., Baltic Sea; Balzer et al. 1987), but it can be narrower than that (e.g., Grossman 1984).

Under favorable circumstances, the position of the sulfate reduction zone can be estimated in the fossil state; indicators of slow sedimentation may reflect the position of the previous seafloor, and the nodule-rich horizon below represents the sulfate reduction zone. Such a situation was encountered four times. The layers rich in

\section{$\delta^{18} \mathrm{O}(\%)$}

$-20-10$

$+1$

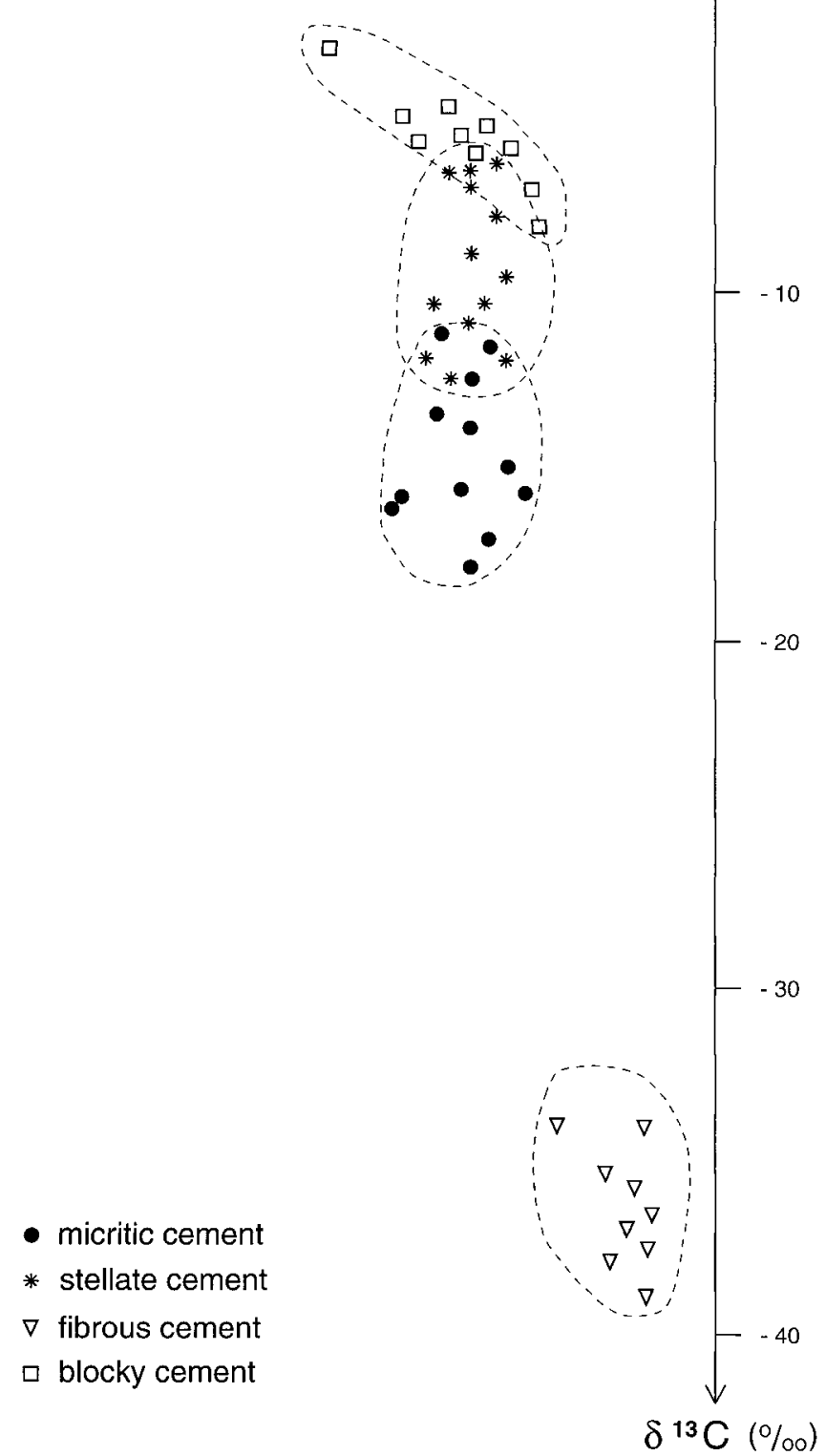

FIg. 12.-Isotope values of the four cement types encountered in the hiatus beds. Micrite values are typical for the sulfate reduction zone. Stellate cement values indicate mixing with previously dissolved carbonate. Fibrous cement carries an isotope signature of methane oxidized in the sulfate reduction zone. The spar cement is of late diagenetic origin.

fossils occur about $10 \mathrm{~cm}$ above the nodule-rich horizon, and its upper and lower boundaries roughly reflect the position of the sulfate reduction zone. After decompaction, the upper boundary of the nodule-rich layers was $30-40 \mathrm{~cm}$ and the lower was $120-150 \mathrm{~cm}$ below seafloor. This is in good agreement with estimation from modern equivalents (see above).

\section{Isotope Data}

The morphologically different cements occupy four fields in a graph of $\delta^{13} \mathrm{C}$ versus $\delta^{18} \mathrm{O}$, suggestive of four discrete geochemical zones (Fig. 12).

Carbon Isotopes.-The alkalinity generated by the microbially mediated decay of even low concentrations of organic matter is enough to overwhelm the alkalinity 


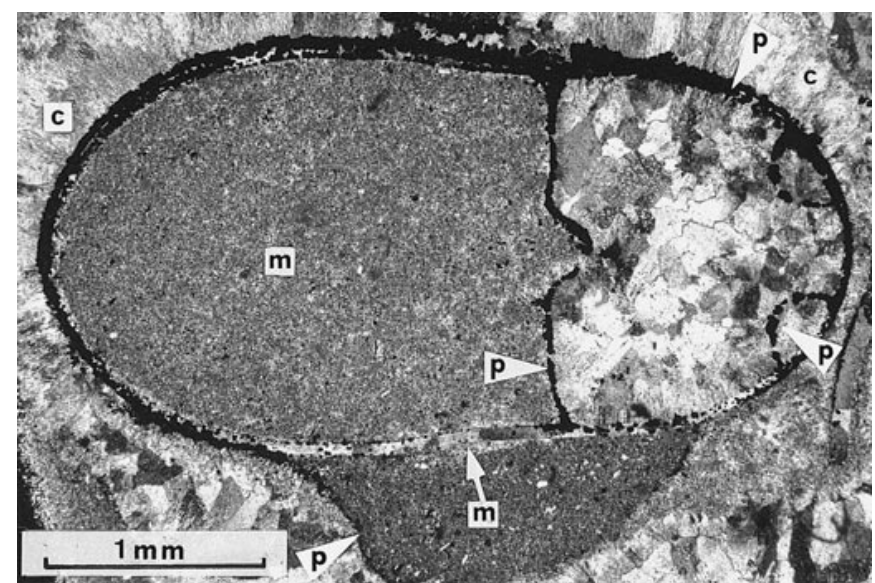

FIG. 13.-In the upper part of the sulfate reduction zone, carbonate of ammonite shell and micrite nodule has been dissolved where exposed to pore fluids (white arrows) and pyrite (p) has been precipitated where carbonate was dissolved; the shell has not been dissolved where it was protected by micrite $(\mathrm{m})$ precipitated during a previous phase of hiatus bed formation; when passing further into the sulfate reduction zone, carbonate (c) was precipitated again (see Figure 11).

originally present in seawater (Coleman and Raiswell 1993). Although $\delta^{13} \mathrm{C}$ of carbonates due to sulfate reduction is theoretically $-25 \%$, typical measured values are -11 to $-18 \%$, suggesting mixing with another carbonate source, probably of marine origin or microbially generated methane (e.g., Coleman and Raiswell 1993; Middleton and Nelson 1996).

The micrite cement shows evidence for such mixing because its isotope signature is somewhat heavier than predicted, but its precipitation within the sulfate reduction zone is indicated by the presence of pyrite (e.g., Von Rad et al. 1996). The micrite could have been directly precipitated by microbes (e.g., Kazmierczak et al. 1996).

The stellate cement carries an isotopic signature suggestive of Fe or Mn reduction (Anderson and Arthur 1983) and related oxidation of organic matter, but corresponding $\mathrm{Fe}$ and $\mathrm{Mn}$ carbonates were not encountered, rather only calcite and pyrite. The latter suggests the formation of stellate cement within the sulfate reduction zone, probably in the upper part just after carbonate was dissolved, resulting in corroded shells and nodules (Figs. 11, 13). Thus, mixing of the dissolved carbonate and the newly produced alkalinity compounds was very likely and led to the wide range of isotope values $\left(\delta^{13} \mathrm{C}-6\right.$ to $-13 \%$ ) of the stellate cement. The variation depends on the amount of dissolved shell material (heavy values) or micrite nodules (light values). The stellate cement might have precipitated under the influence of microbes, as suggested by the experiments of Roberts et al. (1993). The crystals, however, are too large to be precipitated directly within microbes, so we assume that biocatalytic effects of microbial matter induced the formation of the crystals.

Fibrous cements have been documented and debated extensively (see review by Kendall 1985), and it has been argued that filamentous microbes may have affected the growth of the crystals (Mettraux et al. 1989; Violante et al. 1994). In the cases we studied, filaments were not observed within the fibrous cement. The isotopic signature, however, indicates microbial fractionation of the cement carbon. Taking into account the structure of fibrous cement and the wide range of environments where it occurs, for instance reefs, mud mounds, septarian fissures, and travertines (e.g., Kendall 1985, Violante et al. 1994), we conclude that microbes acted as catalysts: the specific membrane structure of certain microbes and oversaturation with respect to carbonate led to precipitation of fibrous cement. An appropriate membrane structure may be found in a large group of microbes corresponding to the wide environmental range of formation of fibrous cement.

Oxygen Isotopes.-The measured oxygen-isotope values of the early cements tend to be 6-8\%o lighter than expected marine values (e.g., Hudson 1977). Such a shift to light oxygen-isotope values is not uncommon for mudstone-hosted concretions (e.g., Hesselbo and Palmer 1992; Burns 1998). The common explanations for this phenomenon are diagenetic alteration of volcaniclastic material, rapid precipitation of carbonate minerals, interaction with organic matter, freshwater influx, and (re)crystallization at elevated temperatures (Burns 1998). None of these explanations is valid for the diagenetic carbonates of the Opalinus Mudstone, for the following reasons:

(1) Altered volcaniclastic material (as described by, e.g., Zimmerle 1982) has not been observed in the studied sections.

(2) Rapid precipitation of carbonates does not significantly affect the isotopic composition of the cements (Burns 1998); furthermore, there is no trend to decreasing isotope values in a nodule from center to rim (see above).

(3) Dynamic equilibrium precipitation (Sass et al. 1991) typically occurs in organic-rich $\left(>5 \% \mathrm{C}_{\text {org }}\right)$ mudstones formed under oxygen-deficient conditions, but such conditions were not met in the Opalinus Mudstone.

(4) Freshwater influx can be excluded: the surrounding mudstones are of very low permeability (similar modern muds have $10^{-7}$ to $10^{-9} \mathrm{~m} / \mathrm{s}$; Silva et al. 1981), and there is no evidence for subaerial emergence of the Opalinus Mudstone (e.g., Etter 1995); also, micrite nodules with the same light oxygen-isotope signature occur throughout the Opalinus Mudstone.

(5) Not all cements show evidence of recrystallization, but all have the light oxygen-isotope values.

All standard explanations for the light oxygen-isotope values are unsatisfactory, and we speculate that the oxygen - now bound in carbonates-was fractionated probably by microbes during sulfate reduction (Cypionka 1994).

\section{Bed Formation}

The basic process for the formation of limestone beds is early precipitation of micrite as single (types I and II) nodules, or a layer formed by diffuse (type III) or coalescing (type IV) nodules (Fig. 14). The micrite occurs in both the nodules of type I and II beds and in micrite-cemented beds of types III and IV. It has the same isotopic composition $\left(\delta^{13} \mathrm{C}-11\right.$ to $-18 \%$ ) that is suggestive of anaerobic oxidation of organic matter in the sulfate reduction zone. The resultant excess alkalinity induced micrite precipitation (Fig. 11).

The nodular micrite within all hiatus beds is similar in geometry, internal fabric, cathodoluminescence color, and isotopic signature to micrite nodules that occur in association with Thalassinoides and other traces throughout the Opalinus Mudstone. We conclude that the nodules were winnowed from these burrow systems. The formation of micrite nodules in burrows has been related to the organic matter in the tube fill (e.g., Ziebis et al. 1996). When buried, the localized surplus of organic matter may have favored microbial activity, including sulfate reduction and resultant precipitation of carbonate.

The nodules needed time to grow; for instance, Coleman and Raiswell (1993) calculated growth times in the range of 7400 to 52,000 years. In contrast to these long time spans, very fast-growing nodules have been reported by Pye et al. (1990) and Moore et al. (1992). These concretions, however, differ significantly in their mineralogy (Fe carbonates) and depositional environment (marsh showing freshwater influx and subaerial exposure) from those studied by the above authors. Because the nodules we studied occur in environments similar to those of the slowly growing ones, we assume-without proof - a similar growth rate. Therefore, the nodules should not have passed through the sulfate reduction zone too fast, and the sedimentation rate must have been lower than the average value for the Opalinus Mudstone; otherwise the nodules would have passed out of the sulfate reduction zone within about 3000 years. It is very likely that the sedimentation rate was reduced before and after exhumation of nodules by storms or currents. In fact, indicators of slow sedimentation, such as horizons rich in fossils, occur close to the nodule-rich layers and support the inference of reduced deposition.

The residence time of the exhumed nodules on the seafloor controlled the degree to which they were bored and encrusted. When buried again, nodules and host sediment returned to the upper part of the sulfate reduction zone, where carbonate dissolution and Fe sulfide precipitation could occur (Figs. 5, 11, 12; see above). Farther down, stellate cement formed with its typical isotopic signature (see above). During subsequent burial, micrite was precipitated having an isotope signature typical of the sulfate reduction zone.

\section{Cavity Systems and Stromatactis-Like Voids}

The cavity systems within the type IV beds have a multiple origin. After initial cementation the first phase of dissolution started in the upper part of the sulfate reduction zone (Fig. 11; see above). The geometry of the cavity systems and the presence of rounded micrite components within the systems suggest that dissolution occurred along the boundaries of coalescing nodules. The second phase of cavity formation in type IV beds is similar to the formation of the stromatactis-like voids in the types II and III beds. Below the sulfate reduction zone, methanogenesis is the main microbial process, simply written as $2 \mathrm{CH}_{2} \mathrm{O}+\mathrm{H}_{2} \mathrm{O}=2 \mathrm{CO}_{2}+4 \mathrm{H}_{2}$ and $\mathrm{CO}_{2}$ $+4 \mathrm{H}_{2}=\mathrm{CH}_{4}+2 \mathrm{H}_{2} \mathrm{O}$ (e.g., Coleman 1993). Thus $\mathrm{CO}_{2}$ is produced and reduced (e.g., Claypool and Kaplan 1974). It is important that dissolved carbon is added as $\mathrm{CO}_{2}$ in the methanogenic zone rather than as $\mathrm{HCO}_{3}{ }^{-}$in the sulfate reduction zone, and hence alkalinity decreases (Rice and Claypool 1981) unless significant Fe reduction accompanies methanogensis (Raiswell 1987). The decrease in alkalinity due to $\mathrm{CO}_{2}$ production may be buffered by dissolution of carbonate, which results in enlargement of the cavities of type IV beds and formation of the stromatactis-like 


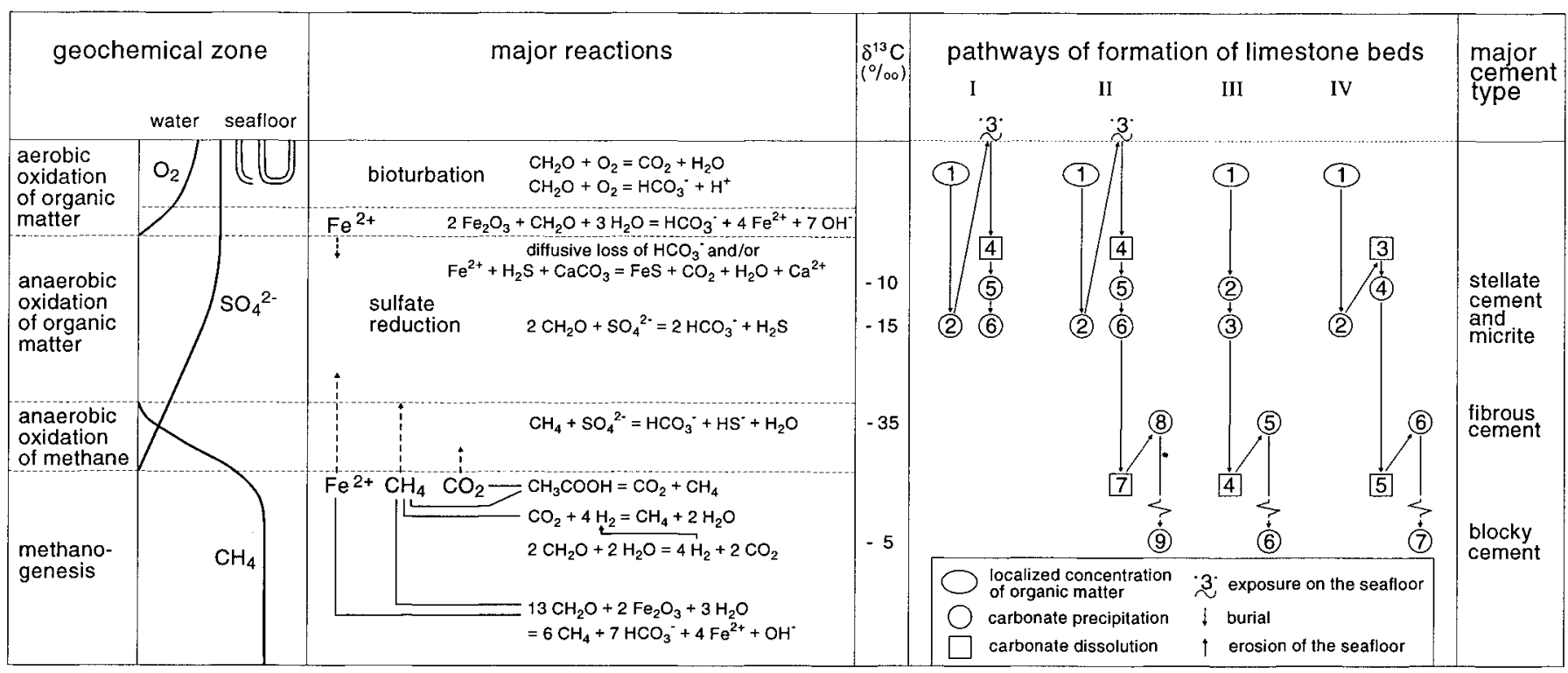

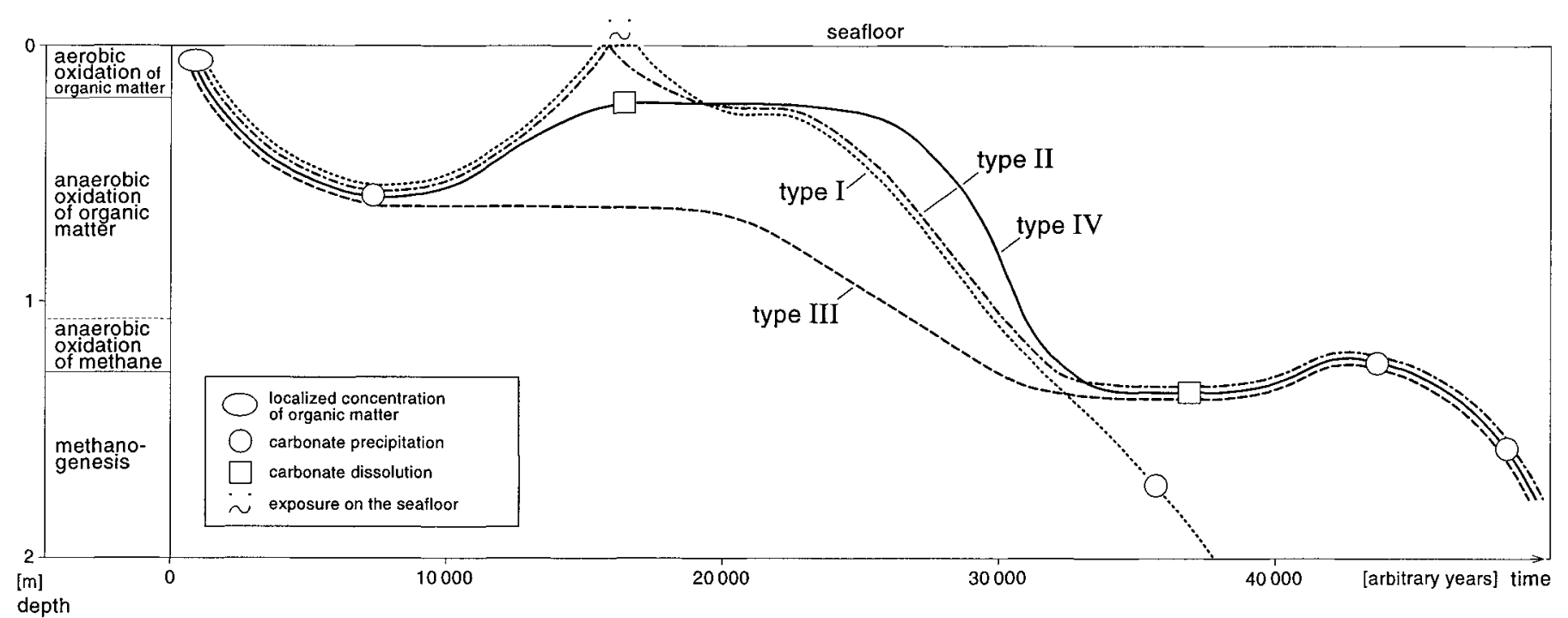

FIG. 14.-Different pathways for the four types of hiatus beds in relation to geochemical zones (see Figure 11) and processes (upper part) and versus time (lower part). Precipitation and dissolution of carbonate are controlled by diffusion, presumably requiring stable geochemical conditions for at least several thousands of years. Thus, each precipitation and dissolution step indicates a phase of reduced sedimentation preventing passage of the hiatus beds into another geochemical zone, as illustrated by the diagram of depth versus time (lower part). Time is in arbitrary years because there is no exact temporal control; depth, in meters, is regarded as equivalent to modern analogues.

voids found in the types II and III beds. Thereafter carbonate (and some pyrite) precipitated repeatedly, producing a laminated infill (Fig. 10).

The voids and cavities were formed by dissolution, which is controlled by diffusion. Dissolution may have required considerable time spans, during which the developing hiatus beds resided in a carbonate-dissolving environment. The large voids, therefore, document periods of reduced sedimentation. The required long time of retarded burial to form them represents an unusual situation. This may be the reason why such dissolution features are not generally observed in hiatus beds and concretions.

\section{DISCUSSION}

The different types of hiatus beds formed in response to similar processes (Fig. 12). The differences between the four types are explained by variations in sedimentation and erosion, which determined the residence time of the specific layers within the geochemical zones. Cementation by micrite indicates prolonged residence time within the sulfate reduction zone and, hence, reduced sedimentation on the seafloor.
Thereafter, erosion might have occurred; in the case of strong erosion, the freshly formed nodules became exhumed, bored, and encrusted (types I and II), whereas in case of slight erosion, the micrite-cemented layers were placed in the upper part of the sulfate reduction zone and dissolution occurred (type IV). The rate and continuity of sedimentation during reburial of the exhumed nodules controlled whether or not dissolution occurred. In case of high and continuous sediment input, additional cement precipitated. If sedimentation was reduced when the developing hiatus bed was within the upper part of the sulfate reduction zone (type II), or within the upper zone of methanogenesis (types III and IV), voids and cavities were formed by dissolution. Consequently, hiatus beds with voids or cavities are indicative of multiple interruptions of sedimentation.

The hiatus beds occur in the opalinum and comptum ammonite subzones at varying frequencies of 0-3 per section, mainly at the base, in the middle, and/or on top (Fig. 15). The biostratigraphic control and the observed pattern excludes their synchronous formation. Therefore, a unifying process such as sealevel change very probably did not control the formation of the hiatus beds. Alternatively, differential subsidence provides an explanation. The decompacted thickness of the hiatus-bed- 


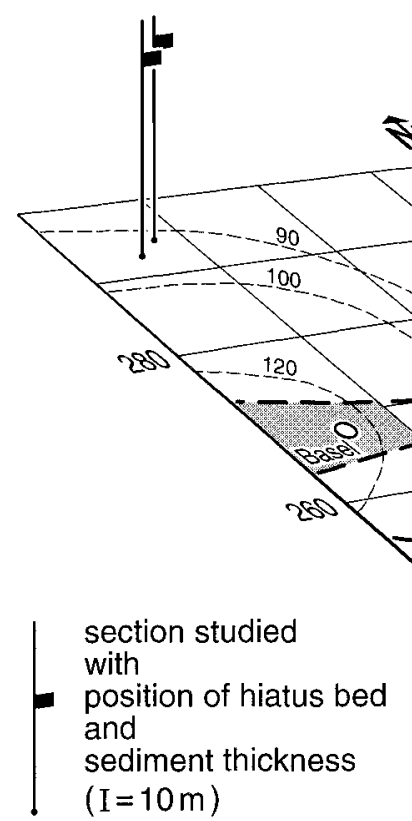

isopach of Aalenian Mudstone
A. WETZEL AND V. ALLIA

FIG. 15.-Oblique map of the study area showing occurrence of hiatus beds within the studied sections, isopachs of the Opalinus Mudstone, and the outlines, as known so far, of the Permo-Carboniferous troughs; the trough in the eastern part is well known (e.g., Diebold 1988) whereas the boundaries of the trough in the western part are more tentative (Boigk and Schöneich 1970; Laubscher 1986). Differential subsidence is indicated by lateral impersistence of hiatus beds (suggesting their diachroneity), more frequent occurrence of hiatus beds along the rims of the trough in the basement, increase in sediment thickness above the trough in the basement, and domains where hiatus beds occur at a similar level, i.e., western, southeastern, and eastern part.

\section{Late Paleozoic graben}

\section{Swiss coordinate grid}

hosting mudstones of $230 \mathrm{~m}$ exceeds the depositional water depth at or below storm wave base. Thus, the accommodation space was provided during sedimentation (see above). Such subsidence rates resulted not only from overburden-induced compaction and isostasy but also from tectonic subsidence-likely at least $25 \%$ of the accommodation space (Allia 1996). In fact, tectonic activity within the basement is documented by altered upper Paleozoic rocks that now provide an Aalenian radiometric age and indicate hydrothermal activity at that time (Schaltegger et al. 1995). Aalenian movements were related to extension in the Tethyan and Atlantic realm (e.g., Lemoine et al. 1986), and the area in between was affected by extensional stresses (e.g., Philippe et al. 1996). Further evidence for reactivation of preexisting grabens and normal faults within the basement and resultant differential subsidence is shown by increased sediment thicknesses above grabens (Fig. 15). There, blocks rotated slightly along listric faults and led to additional differentiation of the seafloor topography. The hiatus beds were formed on such swells (Figs. 15, 16). Because sediment thickness is not significantly reduced where hiatus beds occur, the swells were certainly not permanently elevated in the rapidly subsiding basin.

The hiatus beds in the Opalinus Mudstone illustrate clearly the importance of differential subsidence for their formation. Thus, the question arises how tectonism in general affected the formation of hiatus beds and hiatus concretions. Observations from this study, as well as the hiatus beds reported by Wignall (1989) and Hesselbo and Palmer (1992) that formed on differentially subsiding swells, suggest that the number of hiatus beds that formed in this way has most likely been underestimated.

Hiatus concretions do not occur at uniform frequencies in the rock record. The Ordovician, Jurassic and Cretaceous seem to contain significantly more hiatus concretions and hiatus beds (Wilson and Palmer 1992). Third-order sealevel changes have often been thought to control the formation of hiatus concretions and hiatus beds (e.g., Van Wagoner et al. 1988; Fürsich et al. 1991). If we consider the better documented post-Paleozoic sealevel changes (e.g., Haq et al. 1987), third-order sealevel changes are not thought to vary significantly in period and amplitude through time, yet the frequency of hiatus concretions does. Therefore, sealevel changes alone are not sufficient to explain the stratigraphic frequency of hiatus beds. Shelf bathymetry may play an important role. During long nonglacial time intervals the shelf was probably located in water shallower than today (Hay and Southam 1977). Therefore a larger proportion of the shelf area than today was affected by storms that could winnow out concretions and form hiatus beds. If shelf hypsography, however, was the only factor that led to these perceived maxima in hiatus bed distribution, the Tertiary and Triassic should show increased frequencies of hiatus concretions, but apparently they do not.

The breakup of Pangea increased the area of shelves significantly (e.g., Wyatt 1986). This occurred mainly during the Jurassic and Cretaceous (e.g., Ziegler 1990). Furthermore, until breakup was achieved, rotation of blocks within an extensional regime led to differential subsidence. We conclude, therefore, that the frequency of hiatus beds on a long time scale resulted from several processes: a roughly constant background distribution related to sealevel changes, and a long-term, changing proportion related to hypsography of shelves and differential subsidence.

\section{CONCLUSIONS}

Limestone beds-termed hiatus beds-formed in the nearly carbonate-free shallow-water Aalenian mudstones of northern Switzerland by discontinuous sedimentation and erosion. Anaerobic oxidation of organic matter by microbes provided excess alkalinity, inducing carbonate precipitation. The biogeochemical carbonate factory fluctuated as indicated by a distinct cement stratigraphy.

Four main types of cement occur, each characterized by a distinct morphology and isotope signature: (1) micrite $\left(\delta^{13} \mathrm{C}-10\right.$ to $-20 \%$; anaerobic oxidation of organic matter); (2) stellate calcite cement $\left(\delta^{13} \mathrm{C}-5\right.$ to $-10 \%$; anaerobic oxidation of organic matter and mixing with dissolved carbonate); (3) fibrous cement $\left(\delta^{13} \mathrm{C}\right.$ $-30 \%$; methane oxidation); and (4) blocky calcite $\left(\delta^{13} \mathrm{C}-5 \%\right.$; late diagenesis). Except for the late blocky cement, all cements contain pyrite, indicating carbonate precipitation within the sulfate reduction zone.

The hiatus beds document several phases of cementation and dissolution of carbonate, all being related to biochemical processes and diffusion. Thus, to form or to dissolve significant amounts of carbonate requires a protracted period of time during which geochemical conditions must have remained constant; we envision at least several thousands of years. While being in a rapidly accumulating environment (sedimentation rate about $30 \mathrm{~cm} / \mathrm{kyr}$ ), sufficiently long residence times within a specific geochemical zone can be achieved only if sedimentation rate becomes strongly reduced. Such phases of reduced sedimentation occurred repeatedly.

The hiatus beds did not form simultaneously across the study area and were probably not related to sealevel changes. They probably formed on short-lived swells that resulted from differential subsidence when fault-block rotation produced seafloor topography. Because of different orientations, preexisting faults would have become reactivated even by subtle changes of the paleo-stress field. Thus, the swells did not develop simultaneously. Differential subsidence was induced by reactivation of basement structures.

Hiatus beds in general can be interpreted in terms of sequence stratigraphy and can be related to sealevel changes. However, it has to be taken into account that differential subsidence can lead to the same effect. This may provide a reasonable explanation for maximum in hiatus beds during the Jurassic and Cretaceous-they formed on the newly formed shallow shelves when Pangea broke up.

\section{ACKNOWLEDGMENTS}

This study would not have been possible without the help of various persons and institutions. All isotope data were measured at the Stable Isotope Laboratory of the 

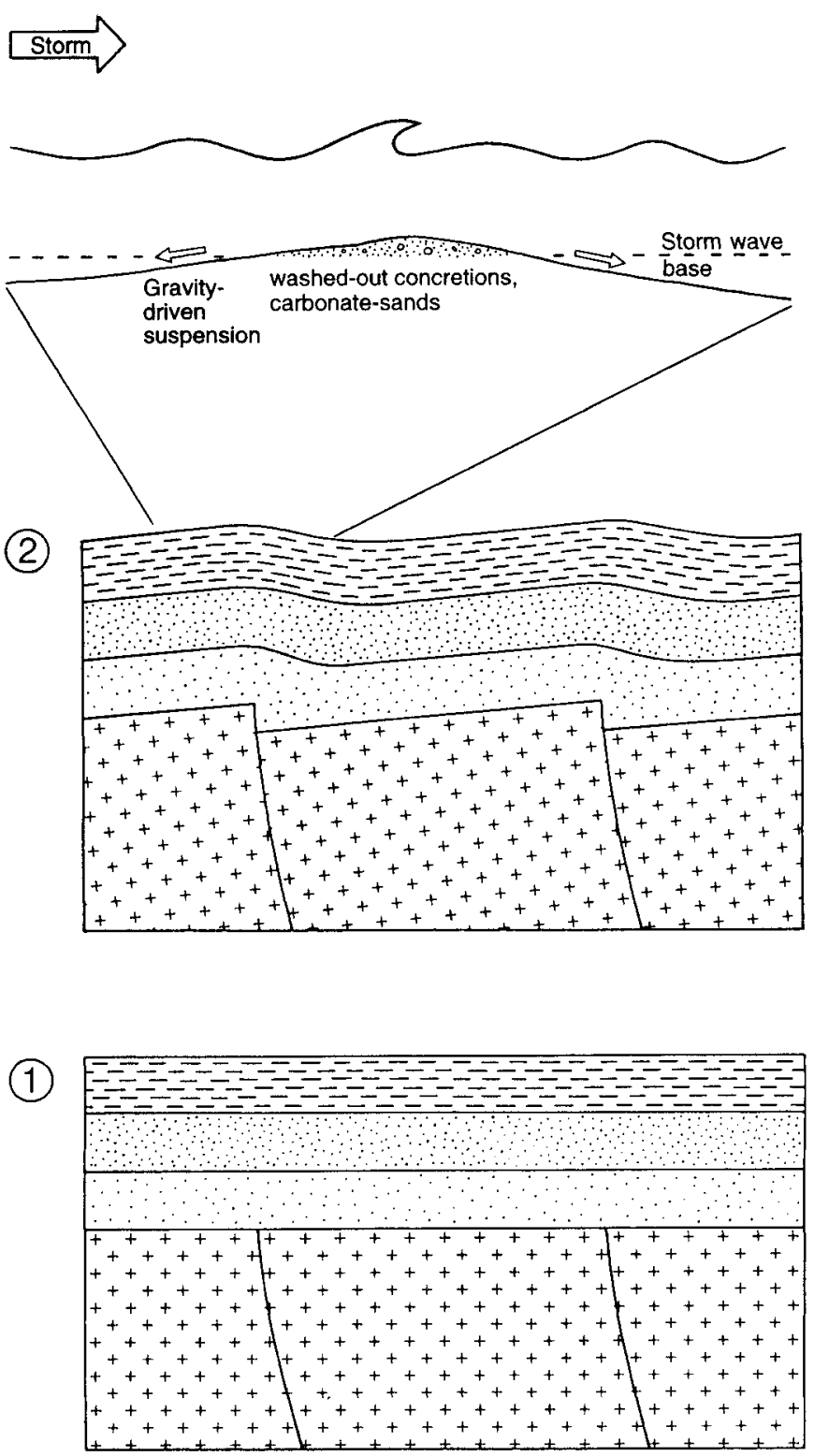

FIG. 16.-Schematic diagram illustrating the formation of hiatus beds on swells resulting from differential subsidence induced by reactivated basement structures. On swells, reduced sedimentation and seafloor erosion provided the conditions suitable for formation of hiatus beds.

ETH Zürich (Switzerland), supervised by J.A. McKenzie. W. Ohmert (Freiburg, Germany) showed us several outcrops in southwest Germany and provided valuable stratigraphic information. B. Pratt (Saskatoon, Canada) and H. Weissert (Zürich, Switzerland) read earlier versions of the manuscript and provided helpful comments, as also the Journal reviewers J. Schieber (Arlington, Texas) and S. Hesselbo (Oxford, U.K.). S. Lauer (Basel) drew all the figures. The Schweizerische Nationalfond zur Förderung der Wissenschaftlichen Forschung (Swiss National Science Foundation) provided financial support (grants no. 21-31115.91, 20-37269.93, and 21-43103.95). All these contributions are gratefully acknowledged.

\section{REFERENCES}

Allia, V., 1996, Sedimentologie und Ablagerungsgeschichte des Opalinustons in der Nordschweiz: Universität Basel, Geologisch-Paläontologisches Institut, Dissertationen, v. 10, 185 p. Anderson, T.F., AND Arthur, M.A., 1983, Stable isotopes of oxygen and carbon and their application to sedimentologic and paleoenvironmental problems, in Arthur, M.A., ed., Stable Isotopes in Sedimentary Geology: SEPM, Course Notes 10, p. 1-1-1-151.
BAIRD, G.C., 1976, Coral encrusted concretions: a key to recognition of a 'shale-on-shale' erosion surface: Lethaia, v. 14, p. 105-122.

Balzer, W., Erlenkeuser, H., Hartmann, M., Müller, P.J., and Pollehne, F., 1987, Diagenesis and exchange processes at the benthic boundary layer, in Rumohr, J., Walger, E., and Zeitschel, B., eds., Seawater-Sediment Interactions in Coastal Waters: Berlin, SpringerVerlag, Lecture Notes on Coastal and Estuarine Studies 13, p. 111-161.

BathuRst, R.G.C., 1982, Genesis of stromatactis cavities between submarine crusts in Palaeozoic carbonate mud buildups: Geological Society of London, Journal, v. 139, p. 165-181.

Boigk, H., And Schöneich, H., 1970, Die Tiefenlage der Permbasis im nördlichen Teil des Oberrheingrabens, in Illies, J.H., and Müller, S., eds., Graben Problems: International Upper Mantle Project, Scientific Report 27, Stuttgart, Schweizerbart, p. 45-55.

Branger, P., ANd Gonnin, C., 1994, Distribution des ammonites et dynamique sédimentaire sur le seuil du Poitou de l'Aalénien au Bajocien: Servizio Geologico Nazionale (Italy), Miscellanea, v. 5, p. 293-295.

BuRNs, S.J., 1998, Can diagenetic precipitation of carbonate nodules affect pore-water oxygen isotope ratios?: Journal of Sedimentary Research, v. 68, p. 100-103.

Canfield, D.E., And Raiswell, R., 1991, Carbonate precipitation and dissolution-its relevance to fossil preservation, in Allison, P.A., and Briggs, D.E.G., eds., Taphonomy: Releasing the Data Locked in the Fossil Record: New York, Plenum, Topics in Geobiology 9, p. 411453.

Claypool, G.E., and Kaplan, I.R., 1974, The origin and distribution of methane in marine sediments, in Kaplan, I.R., ed., Natural Gases in Marine Sediments: New York, Plenum, p. 99-139.

Coleman, M.L., 1993, Microbial processes: controls on the shape and composition of carbonate concretions: Marine Geology, v. 113, p. 127-140.

Coleman, M.L., and Raiswell, R., 1993, Microbial mineralization of organic matter: mechanisms of self-organization and inferred rates of precipitation of diagenetic minerals: Royal Society [London], Philosophical Transactions, Series A, v. 344, p. 69-87.

Curtis, C.D., Coleman, M.L., And Love, L.G., 1986, Pore water evolution during sediment burial from isotopic and mineral chemistry of calcite, dolomite and siderite concretions: Geochimica et Cosmochimica Acta, v. 50, p. 2321-2334.

CyPIONKA, H., 1994, Novel metabolic capacities of sulfate-reducing bacteria, and their activities in microbial mats, in Stal, L.J., and Caumette, P., eds., Microbial Mats: NATO Advanced Science Institute Series, Series G, Ecological Sciences 35, Berlin, Springer-Verlag, p. 367 376.

Diebold, P., 1988, Der Nordschweizer Permokarbon-Trog und die Steinkohlenfrage der Nordschweiz: Naturforschende Gesellschaft in Zürich, Vierteljahresschrift, v. 133, p. 143-174.

ETtER, W., 1995, Benthic diversity patterns in oxygenation gradients: an example from the Middle Jurassic of Switzerland: Lethaia, v. 28, p. 259-270.

FüRsich, F.T., 1979, Genesis, environments, and ecology of Jurassic hardgrounds: Neues Jahrbuch für Geologie und Paläontologie, Abhandlungen, v. 158, p. 1-63.

Fürsich, F., AND BAIRD, G.C., 1975, Taphonomy and biologic progression associated with submarine erosion surfaces from the German Lias: Neues Jahrbuch für Geologie und $\mathrm{Pa}$ läontologie, Monatshefte, v. 1975, p. 321-338.

Fürsich, F.T., Oschmann, W., Jaitly, A.K., AND Singh, I.B., 1991, Faunal response to transgressive-regressive cycles: example from the Jurassic of western India: Palaeogeography, Palaeoclimatology, Palaeoecology, v. 85, p. 149-159.

Grossman, E.L., 1984, Carbon isotopic fractionation in live benthic foraminifera-comparison with inorganic precipitate studies: Geochimica et Cosmochimica Acta, v. 48, p. 1505-1512.

Hallam, A., 1969, A pyritized limestone hardground in the Lower Jurassic of Dorset (England): Sedimentology, v. 12, p. 231-240.

HaQ, B.U., Hardenbol, J., and VaIL, P.R., 1987, Chronology of fluctuating sea levels since the Triassic: Science, v. 235, p. 1156-1167.

HaY, W.W., and Southam, J.R., 1977, Modulation of marine sedimentation by the continental shelves, in Andersen, N.R., and Malahoff, A., eds., The Fate of Fossil Fuel $\mathrm{CO}_{2}$ in the Oceans: New York, Plenum, p. 569-604.

Hesselbo, S.P., and Palmer, T.J., 1992, Reworked early diagenetic concretions and the bioerosional origin of a regional discontinuity within the British Jurassic marine mudstones: Sedimentology, v. 39, p. 1045-1065.

Hudson, J.D., 1977, Stable isotopes and limestone lithification: Geological Society of London, Journal, v. 133 , p. 637-660.

Kazmierczak, J., Coleman, M.L., Gruszczynski, M., and Kempe, S., 1996, Cyanobacterial key to the genesis of micritic and peloidal limestones in ancient seas: Acta Palaeontologica Polonica, v. 41, p. 319-338.

Kendall, A.C., 1985, Radiaxial fibrous calcite: a reappraisal, in Schneidermann, N., and Harris, P.M., eds., Carbonate Cements: SEPM, Special Publication 36, p. 59-77.

Kendall, C.G.St.C., and Schlager, W., 1981, Carbonates and relative changes in sea level: Marine Geology, v. 44, p. 181-212.

Kennedy, W.J., Lindholm, R.C., Helmold, K.P., and Hancock, J.M., 1977, Genesis and diagenesis of hiatus- and breccia-concretions from the mid-Cretaceous of Texas and northern Mexico: Sedimentology, v. 24, p. 833-844.

LAUBSCHER, H., 1986, The eastern Jura: relations between thin-skinned and basement tectonics, local and regional: Geologische Rundschau, v. 75, p. 535-553.

Lemoine, M., Bas, T., Arnaud-Vanneau, A., Arnaud, H., Dumont, T., Gidon, M., Bourbon, M., de Graciansky, P.-C., Rudkiewicz, J.-L., Megard-Galli, J., and Tricart, P., 1986, The continental margin of the Mesozoic Tethys of the Western Alps: Marine and Petroleum Geology, v. 3, p. 179-199.

Loutit, T.S., Hardenbol, J., Vail, P.R., and Baum, G.R., 1988, Condensed sections: the key of age determination and correlation of continental margin sequences, in Wilgus, C.K. Hastings, B.S., Kendall, C.G.St.C., Posamentier, H.W., Ross, C.A., and Van Wagoner, J.C., eds., Sea-Level Changes: An Integrated Approach: SEPM, Special Publication 42, p. 183 213. 
Mettraux, M., Weissert, H., and Homewood, P., 1989, An oxygen-minimum palaeoceanographic signal from Early Toarcian cavity fills: Geological Society of London, Journal, v. 146, p. 333-344.

Middleton, H.A., And Nelson, C.S., 1996, Origin and timing of siderite and calcite concretions in late Palaeogene non- to marginal marine facies of the Te Kuiti Group, New Zealand: Sedimentary Geology, v. 103, p. 93-115.

Moore, S.E., Ferrell, R.E., JR., and Aharon, P., 1992, Diagenetic siderite and other ferroan carbonates in a modern subsiding marsh sequence: Journal of Sedimentary Petrology, v. 62, p. $357-366$.

Ohmert, W., And Rolf, C., 1994, The Aalenian boundaries at Wittnau (Oberrhein area, southwest Germany): Servizio Geologico Nazionale (Italy), Miscellanea, v. 5, p. 33-61.

Philippe, Y., Coletta, B., Deville, E., And Mascle, A., 1996, The Jura fold-and-thrust belt: a kinematic model based on map-balancing, in Ziegler, P.A., and Horvàth, F., eds., Peri-Tethys Memoir 2: Structure and Prospects of Alpine Basins and Forelands: Muséum National d'Histoire Naturelle, Mémoires 170, Paris, Éditions du Muséum Paris, p. 235-261.

Pye, K., Dickson, J.A.D., Schiavon, N., Coleman, M.L., and Cox, M., 1990, Formation of siderite-Mg-calcite-iron sulphide concretions in intertidal marsh and sandflat sediments, north Norfolk, England: Sedimentology, v. 37, p. 325-343.

RAISWELL, R., 1987, Non-steady state microbiological diagenesis and the origin of concretions and nodular limestones, in Marshall, J.D., ed., Diagenesis of Sedimentary Sequences: Geological Society of London, Special Publication 36, p. 41-54.

RAISWELL, R., 1988, Chemical model for the origin of minor limestone-shale cycles by anaerobic methane oxidation: Geology, v. 16, p. 641-644.

Rice, D.D., and Claypool, G.E., 1981, Generation, accumulation, and resource potential of biogenic gas: American Association of Petroleum Geologists, Bulletin, v. 65, p. 5-25.

Roberts, H.H., Aharon, P., and Walsh, M.M., 1993, Cold-seep carbonates of the Louisiana continental slope-to-basin floor, in Rezak, R., and Lavoie, D.L., eds., Carbonate Microfabrics: Berlin, Springer-Verlag, Frontiers in Sedimentary Geology 6, p. 95-104.

Sass, E., Bein, A., and Almogi-Labin, A., 1991, Oxygen-isotope composition of diagenetic calcite in organic-rich rocks: evidence for ${ }^{18} \mathrm{O}$ depletion in marine anaerobic pore water: Geology, v. 19, p. 839-842.

SAVRDA, C.E., AND BotTJer, D.J., 1988, Limestone concretion growth documented by tracefossil relation: Geology, v. 16, p. 908-911.

Schaltegger, U., Zwingmann, H., Clauer, N., Laroue, P., and Stille, P., 1995, K-Ar dating of a Mesozoic hydrothermal activity in Carboniferous to Triassic clay minerals of northern Switzerland: Schweizerische Mineralogische und Petrographische Mitteilungen, v. 75, p. $163-176$.

SchmidT, R., 1996, Feinstratigraphie des Opalinuston (Dogger alpha) der mittleren Schwäbischen Alb, Baden-Württemberg: Planetary Stratigraphy, Series E, 1, Tübingen, Edition Schmidt.

Silva, A.J., Hetherman, J.R., and Calnan, D.I., 1981, Low-gradient permeability testing of fine-grained marine sediments, in Zimmie, T.F., and Riggs, C.O., eds., Permeability and Groundwater Contaminant Transport: American Society for Testing and Materials, Special Technical Publication 746, p. 126-136

SPEARS, D.A., 1989, Aspects of iron incorporation into sediments with special reference to the Yorkshire Ironstones, in Young, T.P., and Taylor, W.E.G., eds., Phanerozoic Ironstones: Geological Society of London, Special Publication 46, p. 19-30.
Van Wagoner, J.C., Posamentier, H.W., Mitchum, R.M., Vail, P.R., Sarg, J.F., Loutit, T.S., AND Hardenbol, J., 1988, An overview of the fundamentals of sequence stratigraphy and key definitions, in Wilgus, C.K., Hastings, B.S., Kendall, C.G.S.C., Posamentier, H.W., Ross, C.A., and Van Wagoner, J.C., eds., Sea-Level Changes: An Integrated Approach: SEPM, Special Publications 42, p. 39-45.

Violante, C., Ferreri, V., D’Argenio, B., and Golubic, S., 1994, Quaternary travertines at Rocchetta a Volturno (Isernia, central Italy). Facies analysis and sedimentary model of an organogenic carbonate system, in Carannante, G., and Tonielli, R., eds., International Association of Sedimentologists, 15th Regional Meeting, Ischia, Pre-Meeting Fieldtrip Guidebook, p. 3-23.

Voigr, E., 1968, Über Hiatus-Konkretionen (dargestellt an Beispielen aus dem Lias): Geologische Rundschau, v. 58, p. 281-296.

Von Rad, U., Rösch, H., Berner, U., Geyh, M., Marchig, V., and Schulz, H., 1996, Authigenic carbonates derived from oxidized methane vented from the Makran accretionary prism off Pakistan: Marine Geology, v. 136, p. 55-7.

WeTZEL, A., 1990, Interrelationships between porosity and other geotechnical properties of slowly deposited, fine-grained marine surface sediments: Marine Geology, v. 92, p. 105113

Wetzel, A., And Allia, V., 1996, Der Ablagerungsraum des Opalinustons-eine sedimentologische Analyse: Geologisches Landesamt Baden-Württemberg, Informationen, v. 8, p. 2024.

Wetzel, A., Allia, V., Gonzalez, R., And Jordan, P., 1993, Sedimentation und Tektonik im Ostjura: Eclogae Geologicae Helvetiae, v. 86, p. 313-332.

WhITICAR, M.J., 1996, Isotope tracking of microbial methane formation and oxidation: Internationale Vereinigung für Limnologie, Mitteilungen, v. 25, p. 39-54.

Wignall, P.B., 1989, Sedimentary dynamics of the Kimmeridge Clay: tempests and earthquakes: Geological Society of London, Journal, v. 146, p. 273-284.

Wildi, W., Funk, H., Loup, B., Edgardo, A., And Huggenberger, P., 1989, Mesozoic subsidence history of the European marginal shelves of the alpine Tethys (Helvetic realm, Swiss Plateau and Jura): Eclogae Geologicae Helvetiae, v. 82, p. 817-840.

WILSON, M.A., 1985, Disturbance and ecologic succession in an Upper Ordovician cobbledwelling hardground fauna: Science, v. 228, p. 575-577.

Wilson, M.A., And Palmer, T.J., 1992, Hardgrounds and Hardground Faunas: University of Wales, Aberystwyth, Institute of Earth Studies, Publication 9, 131 p.

Wyatt, A.R., 1986, Post-Triassic continental hypsometry and sea level: Geological Society of London, Journal, v. 143, p. 907-910.

Ziebis, W., Forster, S., Huettel, M., and Joergensen, B.B., 1996, Complex burrows of the mud shrimp Callianassa truncata and their geochemical impact in the sea bed: Nature, v. 382, p. 619-622.

Ziegler, P.A., 1990, Geological Atlas of Western and Central Europe: The Hague, Shell Internationale Petroleum Maatschappij.

Zimmerle, W., 1982, Sedimentologische Dünnschliff-Analyse der dunklen Tonsteine von OberApt und Ober-Alb (Niedersächsisches Becken): Geologisches Jahrbuch, Reihe A, v. 65, p. 63-109.

Received 11 September 1998; accepted 5 April 1999. 